\title{
INSKRIPCIE V STREDOVEKOM ARCHEOLOGICKOM MATERIÁLI Z ÚZEMIA SLOVENSKA I.
}

\author{
MICHAL SLIVKA
}

„Sensus verborum est anima legis.“

\begin{abstract}
Abstrakt: V prvej časti práce autor predkladá archeologické nálezy opatrené nápismi, resp. ich skratkami, $v$ rôznej forme písma používaného v období stredoveku a na začiatku novoveku. Zahŕn̆a tak keramický materiál (nádoby, misy, poháre, kachlice, slnečné hodiny, hlinené modely), d'alej zbrane (hlavne meče, nože, dýky, honosný hrot šípu), klúče, sklenené poháre a iné kovoliatecké a kováčske výrobky (torzo zvona, železné dvere). Pokus o dešifrovanie litier nápisov v ich kontextuálnom vyjadrení (aplikácie na biblické texty). Pokus o interpretáciu, resp. reinterpretáciu publikovaných nálezov.
\end{abstract}

Kl'účové slová: nápis - skratky - monogramy - epigrafia (duchovný význam slova) - meče - nože - dýky kl'úče - keramické produkty (interpretácia) - včasný až vrcholný stredovek.

\section{Inscriptions among Medieval Archaeological Material from Slovak Territory I}

Sensus verborum est anima legis.

Abstract: In the first part of the article, the author presents archaeological finds with inscriptions and their abbreviations in various forms, which were in use in medieval times and at the beginning of the modern age. These include pottery (pots, bowls, cups, tiles, sundials, clay moulds), weapons (mostly swords, knives, daggers, a decorated arrowhead), keys, goblets and other metalwork and ironwork products (a bell fragment, iron doors). The author tried to decipher the letters and inscriptions in context (application to Biblical texts) and also attempted to interpret them, as well as to reinterpret some finds already published.

Key words: inscription - abbreviations - monograms - epigraphy (spiritual meaning of words) - swords knives - daggers - keys - pottery - early and high Middle Ages.

Nápisy na stredovekých predmetoch, či už materiálovo (keramika, sklo, kov, kost’, koža, textílie), technikou prevedenia až po celú škálu foriem písma (od súvislého cez nerovnomerný sled písma až po podivné písmená podobné znakom či imitované nápisy) dávajú na jednej strane jasný zmysel, u niektorých s abreviačným vyjadrením, v iných zase s nejasným smerom čítania, čo spôsobuje t’ažkosti ich dešifrácie, nehovoriac o vzt’ahovej interpretácii. Dôležitý je tu paleografický aspekt, nakol'ko nápisy odrážajú celú škálu foriem písma od neustálených románskych variantov až po kanonizovanú gotickú majuskulu alebo minuskulu. Na druhej strane, každé slovo je nositel’om významu. Zvlášt' to platí v krest’anskej filológii stredoveku, ked' má písané slovo vyšší duchovný zmysel - sensus spiritualis (vynikajúco priblížil nemecký bádatel' Friedrich Ohly 1958/1959). Parížsky teológ Richard zo St. Victoru († 1173) túto zásadu formuloval tak, že nielen zvuk slova, ale aj súvisiace veci obsahujú význam (non solum voces, sed et res significativae sunt - Ohly 1958/1959, 3). Stredovek je presiaknutý hlbokou religiozitou a základná funkcia slova je vo vzájomnej komunikácii medzi Bohom a človekom, a rovnako medzi l’ud'mi (Nadolski 2001, 87). Vychádza z prológu Jánovho evanjelia: „Na počiatku bolo Slovo a bez Neho nepovstalo nič z toho, čo povstalo“ (Ján 1,1,3). V knihe pôvodu to zdôrazňuje: „Boh videl a bolo to vel'mi dobré“ (Gen 1,31). Popredný znalec Emanuel Levinas sa týmto inšpiroval a píše: „Zmysel ustanovil tvár (obraz) iného človeka, a každé použivanie slov uvádza sa už vo vnútri pramennej jazykovej relácie, aká je relácia tváre v tvár" (Levinas 1998, 244). Fenomenológovia relígie, hlavne G. wan der Leeuw (1978, 447-449) a M. Eliade (1974), zdôrazňujú magický význam slov v samotnej fyzickej, ale hlavne vo verbálnej a mentálnej rovine (pozri Engelking 1988; Šmahel 1990; Bracha 1991). Samotné slovo vo svojej prirodzenosti (forma a význam) je predestinované do sprostredkovania medzi sférou profanum (zviazané s formou) a sférou sacrum (zviazané s významom). Táto duchovno-materiálna dvojitost' dáva slovu moc kreativity. V takomto duchu musíme pristupovat' aj ku nami skúmanému archeologickému materiálu a pokúsit' sa vidiet' v ňom inkarnovaného ducha výrobcu, odberatel’a (adresáta) alebo ich používatel'a. 
Práca zapadá do širokého multidisciplinárneho okruhu bádania a v konečnom dôsledku spláca dlh v spracovaní nápisového materiálu z územia Slovenska. S jeho projektom Corpus inscriptionum Slovaciae, iniciovaným J. Spiritzom (1996) a súčasne realizovaným J. Šedivým (2006; 2008; 2009; 2014), sa už započalo, nakol'ko v minulom roku vyšiel I. zväzok historických nápisov zo Šariša (Čovan 2016), ktorý nadviazal na predchádzajúce štúdie (Čovan 2011; 2013; 2014). Nemôžeme však opomenút' staršie spracovania epigrafických pamiatok z doby rímskej na Slovensku (Žák-Matyasowszky 2003). Naše snaženie v tomto smere mieni načrtnút' istý výpočet publikovaných i nepublikovaných archeologických pamiatok, ktoré si v budúcnosti zaslúžia katalógové spracovania. Sme si vedomí základného vedeckého postulátu, vyjadreného rímskym príslovím: „Satius est petere fontes quam sectari rivulos“, v prenesenom význame: „Lepšie je skúmat' pôvodný materiál, ako sa spoliehat' na citácie." Publikovaný materiál, niekedy neprístupný alebo aj stratený, nesie v sebe často nesprávne prepisy litier, čím sa stáva nezrozumitel'ný. Týka sa to predovšetkým šperkového materiálu (prstene, spony), ktorým sa budeme venovat' samostatne. V tomto príspevku sa obmedzíme na keramický materiál, zbrane, klúče, sklenené poháre a ojedinelé kovolejárske nálezy.

\section{Keramika}

S prvými znakmi v keramickej produkcii na Slovensku sa stretávame už na konci doby laténskej, o čom svedčia grafémy na dnách nádob z Bratislavy - z hradu (Vrtel' 2012, obr. 277) a z hrnčiarskej pece, odkrytej na Námestí slobody (Zachar 1987, 45, obr. 43). Neberieme do úvahy znaky tzv. lineárneho písma na pravekej keramike (Vel'ká Lomnica, Košice, Vráble), ktoré sú predmetom odbornej diskusie a možno ich za také považovat' len vo vel'mi hypotetickej rovine. Početnejšie zastúpenie majú v nasledujúcej dobe rímskej, ked' hrnčiari svoje výrobky označovali svojimi menami (Hilgers 1969) a kultúra písma nadobudla väčší význam (Scholz 2000; ReuterScholz 2005).
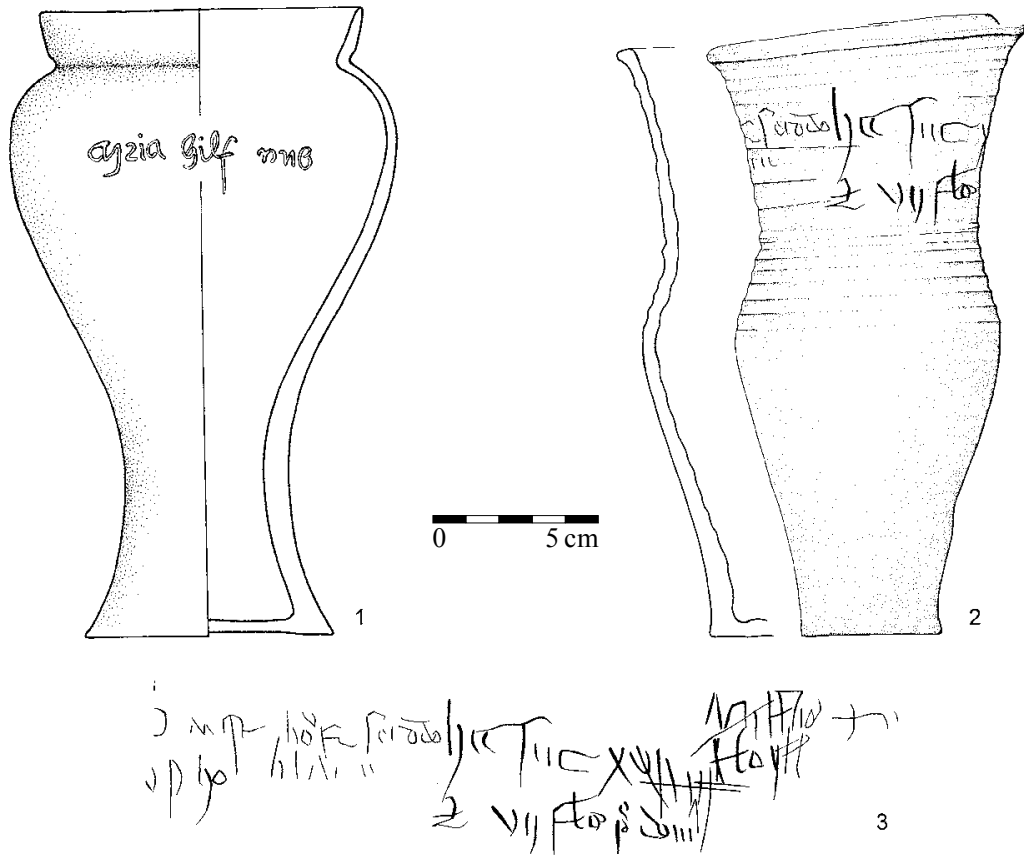

Obr. 1. Ryté nápisy na gotických pohároch. 1 - Bratislava; 2, 3 - Košice.

Abb. 1. Geritzte Inschriften auf gotischen Bechern. 1 - Bratislava; 2, 3 - Košice. 

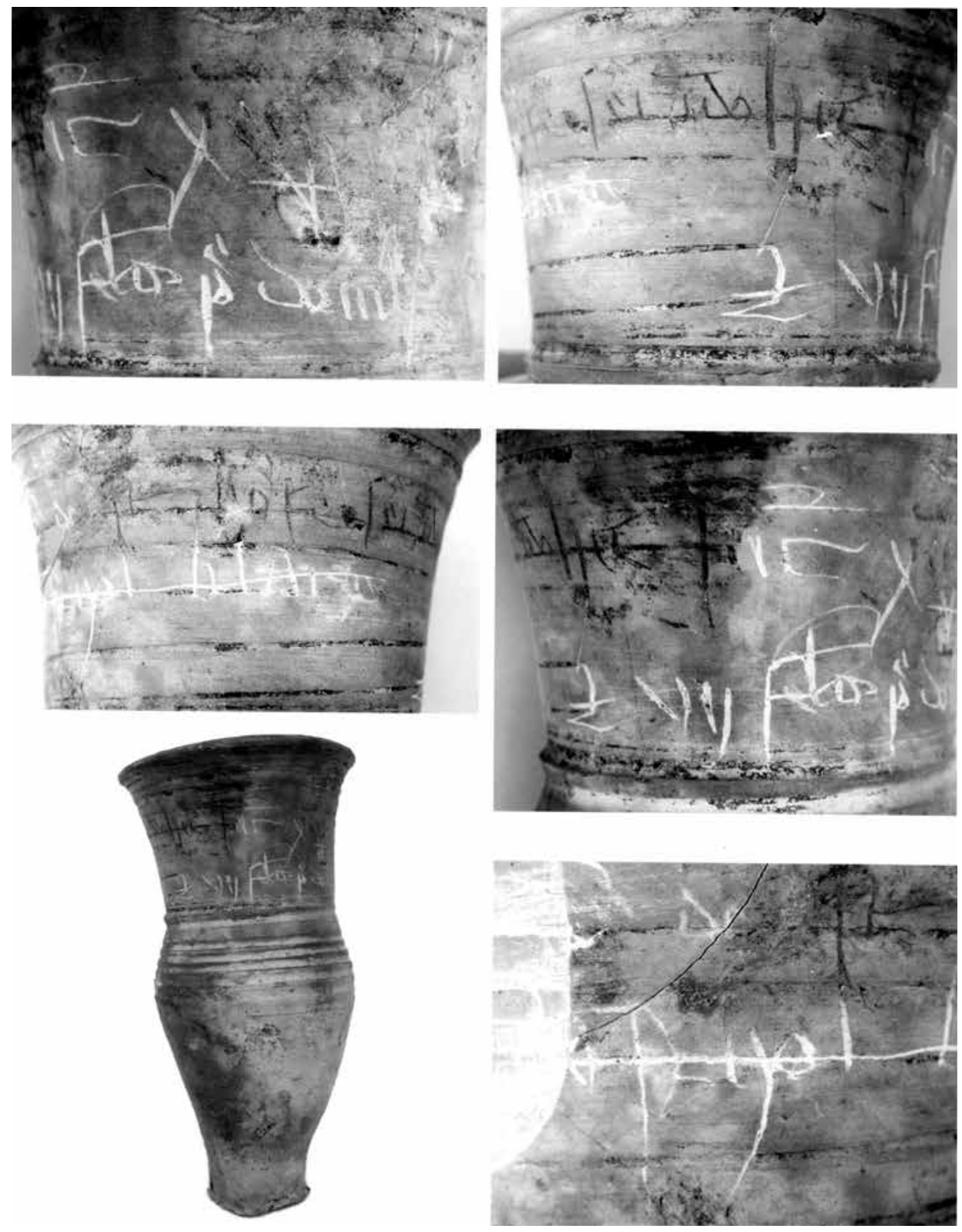

Obr. 2. Košice - Hlavná ul. č. 58. Gotický pohár s latinským nápisom.

Abb. 2. Košice - Hlavná-Str. Nr. 58. Gotischer Becher mit lateinischer Inschrift.

V stredovekom keramickom materiáli sa stretávame s menej zastúpenými rytými nápismi (vyhotovenými zrejme ešte pred vypálením nádob) a radielkovými nápismi, častými v neskorogotickom období a hlavne na území strednej Európy.

Ryté nápisy sa v západnej Európe (Dunning 1967; 1974), ale aj v Čechách (Sezimovo Ústí), na Morave (Olomouc) a na Slovensku (Bratislava, Košice) objavujú len v 15. storočí. Známy tzv. 
Husov hrnček zo začiatku 15. storočia má pri ústí latinský nápis a na pätke počiatočné slová českej piesne „Králi slavný, Kriste dobrý“ (Švehla 1930). Tým sa považuje „,za jednu z nejstaršich zachovaných liturgických nádob středověké hereze“ (Krajíc 2001, 130, obr. 2). Tvar a materiál hrnčeka (výška $10 \mathrm{~cm}$ ) ho aj napriek dobovému ideovému „novátorstvu“ vylučujú ako liturgickú nádobu. Dva keramické fragmenty z Olomouca (Morickej školy) s nápismi Esech(iel) a Reysek J. Bláha len s otáznikom interpretoval ako mená žiakov a datoval ich do obdobia okolo roku 1500 (Bláha 1974, 31). Pravdepodobne sú to mená hrnčiarov. K unikátnym nálezom patrí gotický pohár, ktorý bol nájdený pri záchrannom výskume v jadre mesta Košíc (Hlavná ul. 58), a to v objekte chladnice v súbore dobre zachovaných asi 50 pohárov (Čaplovič 1990, 94, obr. 4). Pohár vysoký $19,2 \mathrm{~cm}$ má nepravidelné ústie s priemerom 10,2 a $8,8 \mathrm{~cm}$, zjavne ide o nepodarok (obr. 1:2 a 2). Nepriamo o tom svedčí aj latinský nápis v jeho podhrdlí, napísaný gotickou kurzívou s pozmenenými tvarmi písmen: do. st hoc ...hic su(n) $t$ XV VIII (škrtnuté) newe? hol hl.... et VII flo(renos)pr(a)e dom(ino)? (obr. 1:3). Obsah nedáva jednoznačný zmysel, i ked' pravdepodobne ide o poznámky k vyúčtovaniu výrobkov na nepodarku alebo podlžnosti azda v tom, že od pána prijal 15 florénov a dlží mu 7 florénov. Aj ked' gramotnost'v tomto období bola v mestách na dobrej úrovni, v štruktúre mestského obyvatel'stva medzi nich nemožno zaradit' hrnčiarov. Helga Hajdu odhadla, že v čase reformácie vedelo čítat' 10-30\% mestských obyvatel'ov, v Norimbergu až $30 \%$ (Hajdu 1931, 30). D. Čaplovič vzhl'adom na vel'ký súbor keramického riadu uvažoval, že „patril do výbavy kupca, majitel'a mestského hostinca(?)“(Čaplovič 1990, 94). Účtovnú agendu na tomto keramickom nepodarku bolo teda možné (pre znalost' písma) zrealizovat' z prostredia vyššieho sociálneho statusu. Emancipačné snahy viedli k nadobudnutiu vzdelania vo vtedajších školách.

Druhý pohár s nápisom „Maria hilf uns“ pochádza z Bratislavy (obr. 1:1), z chladnice v pivnici domu č. 16 na Panenskej ulici (Hoššo 1996, 199, obr. 1:9). Pohár vysoký $10 \mathrm{~cm}$ bol nájdený v uzavretom keramickom súbore, datovanom do poslednej tretiny 15. storočia. Prosebný nápis „Mária pomôž nám“ bol bežne používaný v stredoveku, a to nielen na keramike, ale aj na iných predmetoch - na kovovej nádobe a prsteni z pokladu v Körmende (Vattai 1956, 69, tab. X:6; Zsámbeky 1983, 112, obr. 14), na amulete z pol'ských Chojníc (Wachowski 2013, 56, obr. 22), na pracke z Lelesu (nepubl.), na hrobovom nálezu z Perlata (Hatházi 2004, 213-215, obr. 1:15) atd'.

Na radielkom zdobenej keramike sú počas celého 15. storočia ovel’a početnejšie nápisy typu Maria, resp. Ave Maria. Radielkové nápisy sa objavujú už v 13. storočí, napr. na okraji misky z hrnčiarskej dielne vo Würzburgu s menom „HENRI(C)US“ (Gerlach a kol. 1987, 156-157, 254, obr. 32: 266) alebo na hrnci zo zaniknutej dediny Pfaffenschlag na Morave s nápisom TARNUC a obrátene CUNRAT, na inom fragmente zrkadlovo MMUC.TA/RNUC (Nekuda 1975, 125, obr. $108,123)$. Obidva nápisy majú románske kapitálové písmo a podl’a V. Nekudu „bez významného smyslu“ $(1975,125)$. Hypoteticky by mohlo íst' o mená hrnčiarskych majstrov, aj ked' chýba priamy súvis vo vyjadrení „,me fecit“. Práve v tomto období sa najmasovejšie vyskytujú „sebavyjadrenia majstrov" rôznych profesií, hlavne v stavitel'stve (podpismi i portrétmi - Großmann 2010, 31-34; Gurevič 2016, 162-165).

Ked' pred vyše sto rokmi začal v juhočeskom Sezimovom Ústí miestny učitel' Josef Švehla svoje výkopy a zberatel'skú činnost', jeho výsledkom bol bohatý keramický materiál v početnom zastúpení keramiky zdobenej radielkom. Jeho záujem sa prejavil aj v susednom Tábore a výkopmi na zrúcaninách Kozího Hrádku (Švehla 1901; 1911; 1930; odborné spracovanie Reichertová 1965). Následné odborné výskumy priniesli priame doklady hrnčiarskej výroby: Sezimovo Ústí (Richter 1969; 1978), Tábor (Krajíc 1982) s početnými nálezmi keramiky, opatrenej nápismi gotických majuskulí a miniskulí so vzt’ahom k husitskému obdobiu (Nekuda-Reichertová 1968, 71). Sú to miesta, na ktoré sa po pápežskom exkomunikovaní utiahol teológ Ján Hus v roku 1413 (Kozí Hrádek) a napísal tu svoje reformátorské dielo De Ecclesia, považované za heretické (v júli 1415 v Konstancii bol upálený). Z tohto aspektu dostal tento špecifický druh keramiky označenie, hlavne v pol'skej odbornej spisbe (Mikołajczkyk 1978; Horbacz-Mikołajczkyk-Wojda 1980), „,husitská keramika“ (naposledy Kajzer 1994), i ked’ priama súvislost' s husitstvom nie je považovaná za príliš pravdepodobnú (Andrzejewska 1997, 184). Vlastné nápisy typu maria (marya), 
maria hilf, Ave Maria sa často opakujú v páse na podhrdlí nádob alebo na vytiahnutom okraji misiek. S týmto javom sa možno stretnút' na miniskulnej formule „Ave Maria“, vyhotovenej šablonovitým nápisom v kostole Urschadling (Nemecko), datovaným okolo roku 1400 (Brekle 1999, 210-211, obr. 174), a tiež ustavične opakovaným menom Mária na iných epigrafických pamiatkach (Kloos 1980, 85). Bohatý nález týchto keramických nápisov je i z d’alších českých lokalít: z Louňovic pod Blahníkem (obr. 4:1, 2, 7 - Radoměrský 1964, 20, obr. 16-18; 24-25), z hradu Sion pri Kutnej Hore (Janská 1963, 35, obr. 80), z Plzne (Nechvátal 1976, 94-95, obr. 13:50, 17:84, 19:104, 105 a 26), z Prahy (Pokorná 2002, 129, obr. 7), z Písku (Fröhlich 2002, obr. 14:8, 9), z hradu Valečov (Waldhauser-Sosnovec 2004, 386, obr. 4), z hradu Vimperk (Durdík-Kašpar 2000, obr. 4-6), rovnako z Moravy - Mstěníc (Nekuda 1985, 100, obr. 146: g, 175:d) a z miest Uničov, Olomouc (Šlézar 2016, 194-195, obr. 119) a Kroměříž (Chybová 2009, 156-157). Rovnako sa s nimi stretávame i na území Mad’arska (Buda, Ostrihom, Nagykállót - Parádi 1965), ojedinele aj v Rakúsku (Pittioni 1976, 190, obr. 6), ba až na severe Moldavska (Fedorov-Polevoj 1973, 369, 371, obr. 4) a v holandskom Amsterdame (obr. 4:4 - van Regteren-Zantkuyl 1969, 242, obr. 5:1). Z územia Slovenska sú zatial' známe len tri nápisové exempláre, a to nepublikovaný nápis na miske nájdenej v Bratislave - Academii Istropolitane a $\mathrm{z}$ nádoby a krčiažteka z výskumu kartuziánskeho kláštora v katastri obce Letanovce-Kláštorisko (obr. 3). Nápis gotickej minuskuly „maria hilf“ sa v podhrdlí opakuje a predel'uje ho náznaková monštrancia. Vyhotovený bol z pohl’adu ústia nádoby a azda zámerne je obrátený. Tieto poháre sú datované v horizonte poslednej tretiny 15. storočia. Slovo má pre kartuziánov par excellence totálny význam. Kláštor bol podla kronikárskych záznamov v roku 1433 vyplienený husitskými vojskami a neskôr ho v roku 1454 obsadili bratríci, v dôsledku čoho sa mnísi odst’ahovali do Levoče. Mariánska úcta nadobudla na svojej intenzite, a to nielen v kláštore (konpatrocíniom kostola je P. Mária), ale aj v mestskom prostredí. Tu vznikali mariánske bratstvá (Kežmarok, Levoča) a vtedy sa sformovalo nové pútnické miesto nad mestom Levoča, kde dal farár Servác vybudovat' v rozmedzí rokov 1466-1494 pútnickú svätyňu, zasvätenú Navštíveniu P. Márie (svätenie 2. júla - Slivka 2013, 101). Uvedený príklad jasne svedčí o tom, že tzv. husitská keramika má antihusitský charakter a Mária je tak v istom opozičnom binarizme. Tento fakt vystupuje i v neskorších storočiach, najúčinnejšie v období baroka, poznamenanom v rámci protireformačného hnutia obnovou katolíckej cirkvi. Nápisy Ave Maria boli rovnako uplatnené v stredovekom šperkárskom umení, a to na prsteňoch, napríklad v poklade z Wiener Neustadtu (Zajic 2014, 252-253, 255, obr. 273, 279, 343; Hansmann-Kriss-Rettenbeck 1966, 230-231, obr. 763-808), na šatových sponách alebo opaskových prackách (Fingerlin 1971; Heindel 1986), nákončiach opasku (hrad Šariš - Slivka 1980, 256, obr. 15:24) a v bohatom zastúpení na knižných nárožniciach a sponách (Slivka 2001, obr. 7:9, 2002, obr. na s. 12; Slobodová 2010). Hlboko uctievaná Mária ako Matka Božia, vel'ká král'ovná nebies, sprostredkovatel'ka milostí (akcent Bernarda z Clairvaux) a orodovníčka za l'udí u Boha, je v umení populárne predstavená v plášti chrániacom svojich ctitel’ov, zvlášt' v rehol’ných spoločenstvách, ale aj u svetských fundátorov a mešt’anov. Stala sa žriedlom modlitieb a pobožností v kontemplácii Božieho slova, ktoré sa stalo telom v zhode s Máriou (sv. František, Dominik, Tomáš z Akvinku, Bonaventura). Jej duchovnú krásu i príklad čistoty opísal v Božskej komédii Dante a prostredníctvom piesne Ave Maria od rakúskeho skladatel'a Franza Schuberta († 1828) nesie svoju popularitu dodnes (z množstva literatúry sa odvolávame na Bylina 1984; Weismayer 1994, 105-106; Schreiner 1992, 71-72; 2003; Opitz 1993).

$\mathrm{S}$ nápismi v keramickej produkcii sa stretávame aj u špecificky umeleckého sortimentu, akými sú kachlice. Na rímsovej kachlici z hradu Kežmarok je v minuskule nápis „marya“ (obr. 5:1 - Polla 1971, 50), uvádzaný ako „maria“ (obr. 57, tab. XXXVII:2; Holčík 1978, 125, obr. 56 marya). Analogické nápisy sú na kachliciach z kláštorného prostredia, a to z benediktínskeho kláštora v Rimavských Janovciach (obr. 5:2 - Hrašková-Kürthy-Ragač-Šimkovič 2001, 292, obr. 2:2) a v Rimavskej Sobote - Barátkú (Mníšska studňa - obr. 5:3 - Botoš 2011, 124, tab. 96; Gruia 2013, obr. 340). K nim možno zaradit' aj torzo rímsovej kachlice s cimburím z Banskej Bystrice (Mácelová 1999, 415, obr. 5:1), ako aj nálezy mimo nášho územia (Gruia 2013, 185186). Nad ypsilonom v názve „Marya“ sa pozastavil Z. Hazlbauer a pripísal to na vrub „menej 

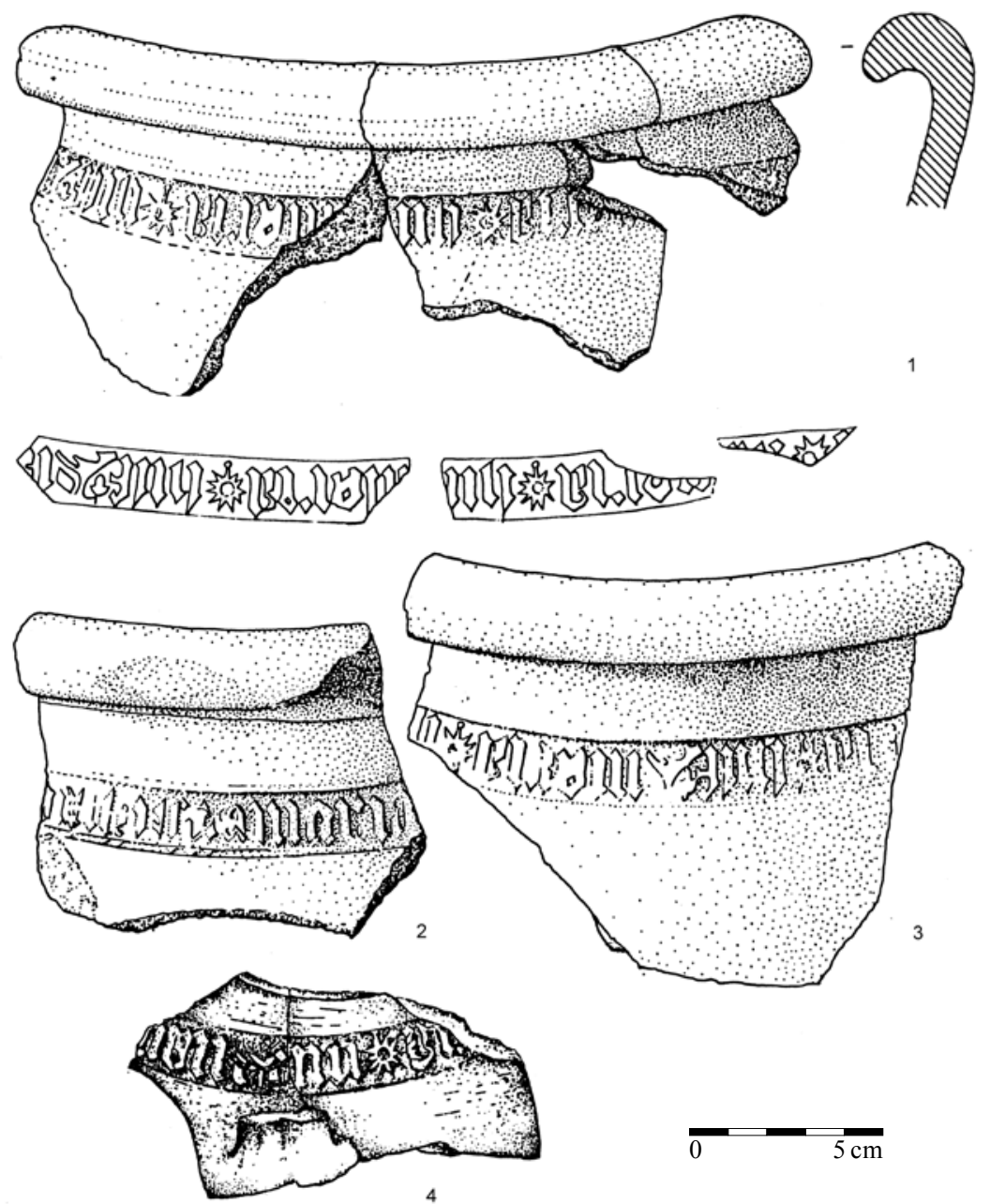

Obr. 3. Letanovce-Kláštorisko. Radielkom zdobená keramika z výskumu kartuziánskeho kláštora z 15. storočia.

Abb. 3. Letanovce-Kláštorisko. Rädchenverzierte Keramik von der Grabung an einem Kartäuserkloster aus dem 15. Jahrhundert.

gramotných výrobcov“ či „rozkolisanosti českého pravopisu v té dobe““ (Hazlbauer 1998, 180). Marya sa vyskytla aj v Rajhradskom evanjeliári z 15. storočia, tiež na spomenutých keramických nádobách (napr. z Plzne - Nechvátal 1976, 95, obr. 13:50) alebo na honosne zdobených hrotoch šípov (Londýn, Praha - „mamyla marya pano“ - Nickel 1969, 106, 161), teda v priebehu celého 15. storočia aj na iných pamiatkach (Trelińska 1991, 40, 62). Tieto fakty sa zaiste netýkajú gramotnosti výrobcov matríc, ktorí svoje námety preberali z rôznych obrazových predlôh. Na kachliciach sú časté mená ich výrobcov (Žegklitz 1987; Hazlbauer 1998, 16-18, 2005), a to predovšetkým na rímsových kachliciach s cimburím. Fragmentálne boli zachytené pri výskume hradu Fil'akovo ešte v roku 1944. Sú na nich majuskulné písmená D.E.BENDE.EDIC (Kalmár 1959, 30, tab. LXI:5-7). Časté sú nápisy na portrétových vyobrazeniach apoštolov, napr. sv. Petra na kachliciach z Banskej Bystrice - na nápisovej páske v minuskulnom vyjadrení „sa petro“ (Holčík 1978, 127, obr. 84; Mácelová 1999, 415, obr. 5:3), evanjelistov - súbor komorových kachlíc 

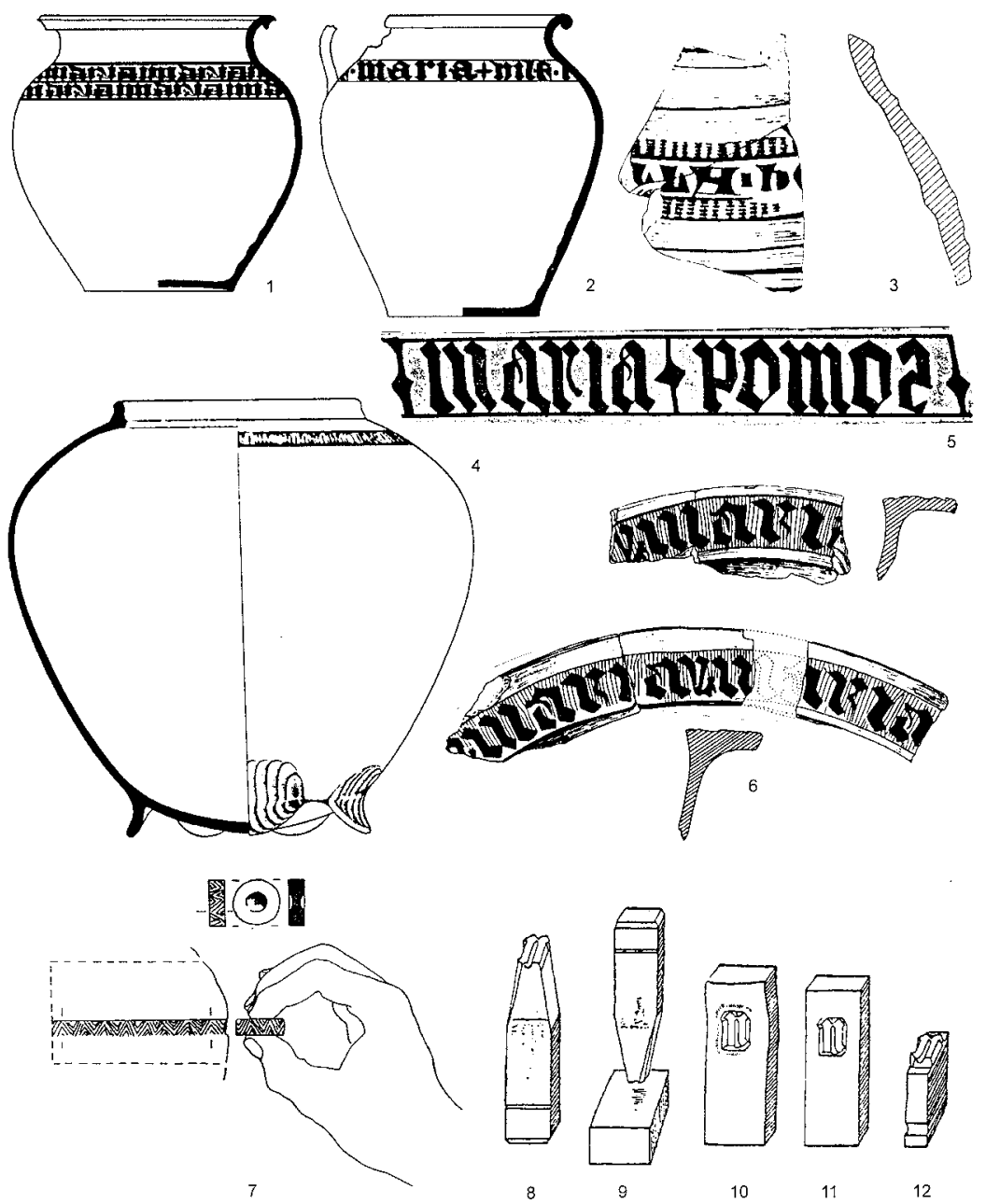

Obr. 4. 1, 2 - Louňovice - kláštor; 3 - Nagykállót, Mad’arsko, nápis „LLA ${ }^{\circ}$ h“; 4 - Amsterdam, nápis „ave maria.ave.maria“; 5 - Sezimovo Ústí, nápis „maria pomoz“ (podl’a J. Švehlu); 6 - Ostrihom, nápis „ave maria“; 7 - kolieskové radielko (podl’a Mikołajezyk 1978, obr. 1); 8, 9 - vrchný diel na formovanie razením (patrica); 10, 11 - matrice; 12 - litera (podl’a Brekle 1999, obr. 172).

Abb. 4. 1, 2 - Louňovice-Kloster; 3 - Nagykállót, Ungarn, Inschrift „LLA ${ }^{\circ} h_{\circ}$ “; 4 - Amsterdam, Inschrift „,ave maria.ave. maria“; 5 - Sezimovo Ústí, Inschrift „maria pomoz“ [Maria hilf] (nach J. Švehla); Ostrihom, Inschrift „ave maria“; 7 Rollrädchen (nach Mikołajczyk 1978, Abb. 1); 8, 9 - Prägestock, Patrize; 10, 11 - Matrize; 12 - Letter (nach Brekle 1999, Abb. 172).

z Letanoviec-Kláštoriska (obr. 6:1-3). Nápisy na nich - IOHANES, MARCVS, LVCAS - majú zrkadlovo obrátené koncové „S“.

Ďalší súbor predstavujú kachlice s vyobrazením proroka Eliáša s tzv. hovoriacou páskou „ELIAS“ (dva exempláre z Banskej Bystrice - Holčík 1978, 126, obr. 81; Mácelová 1999, 415, obr. 5:4), ktoré sa našli vo fragmentárnom stave v Banskej Štiavnici (Šebestová 2005, 53, tab. VIII) a na hrade v Kremnici (Gruia 2013, 185, obr. 7:2, kat. 264 a 313). Všetky nálezy predstavujú profesionálnu kachliarsku výrobu, akou sa v 15. storočí preslávila banskobystrická dielňa. Z tejto produkcie pochádza aj d’alšia kachlica, nájdená pri výskume Komorského dvora v Banskej 


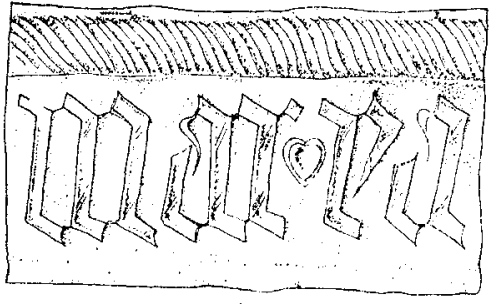

1

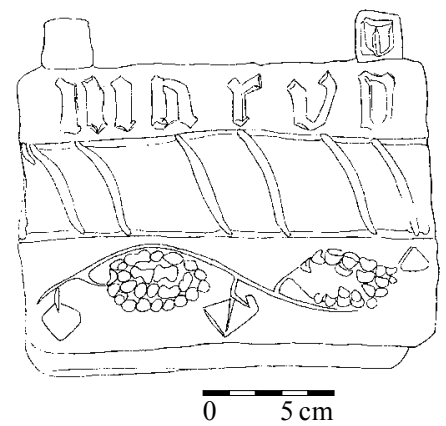

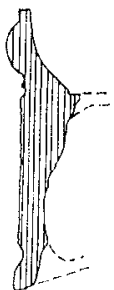

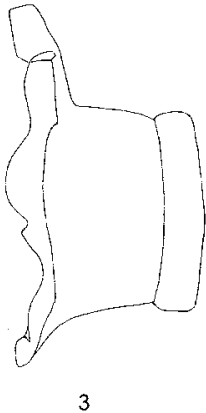

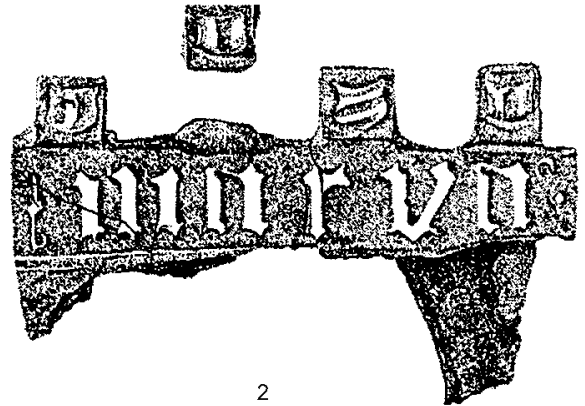

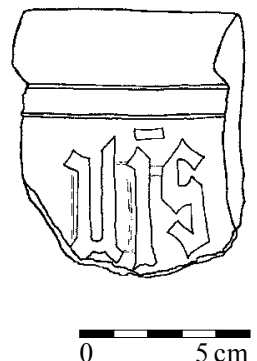

Obr. 5. Kachlice s nápismi „marya“. 1 - Kežmarok-hrad; 2 - Rimavské Janovce - benediktínsky kláštor; 3 - Rimavská Sobota-Barátkút; 4 - Hlohovec-Zámok (nápis ,vis“).

Abb. 5. Kacheln mit Inschrift „marya“. 1 - Kežmarok-Burg; 2 - Rimavské Janovce - Benediktinerkloster; 3 - Rimavská Sobota-Lage Barátkút; 4 - Hlohovec-Schloss (Inschrift ,vis“).

Štiavnici, s postavou Márie Magdalény, držiacou v ruke nádobu s olejom, čo je jej charakteristický atribút, rovnako aj hovoriaca páska „mary(a)...a“ (Holčík 1978, 126, obr. 68). Z výskumu Bratislavského suburbia pochádzajú dve nárožné torzá kachlíc s nápismi „,cta kather“ (sancta Katherin) a druhé, značne ošúchané torzo s nápisom „iamos“? (Polla 1979, 157, 286, obr. 81, tab. XV:7, 11). Neskorogotický nálezový fond uzatvárajú kachlice s nápisom „ihs“, ktorý je na cimburí rímsovej kachlice z hradu Beckov (Holčík 1978, 126, obr. 60). Písmená IHS vo význame „In hoc signo“ alebo „Iesus hominum salvator“ sú monogramom Ježiša Krista, teda ako nomina sacra (Pátková 2014, 144), a odzrkadl'ujú neskorostredoveký prúd pašijnej pobožnosti, propagovanej duchovnými elitami, zvlášt' františkánskymi kazatel'mi. Autorstvo kultu vnútorného symbolu Ježiša - IHS sa pripisuje teológovi a kazatelovi Bernardovi zo Sieny († 1494 - Dombart 1914/1915, 251). V období baroka bol šírený jezuitmi („Iesus habemus socium“ alebo „Iesu humilis societas“). Tí ho v zmysle „Ježiš pre pokorného spoločníka“ prijali do svojho rádového znaku. Monogram sa tak uplatnil na bránach miest a kostolov, ba v detailoch aj na pastafóriách (napr. Dom sv. Martina v Bratislave), svorníkoch (sakristia kostola v Sazdiciach), ale aj na iných drobných predmetoch, napr. vreckové slnečné hodiny z Viedne z roku 1463 (Dombart 1914/1915, obr. na strane 261), knižné spony, barokové prstene (Krásno, Svodín) a iné. Na renesančných kachliciach z pol'ského Rzesowa a Będziemyśla sa nápis ,ihs" nachádza v kruhovom terči, imitovanom tŕňovou korunou (Lubelczyk 2005, obr. 3:6, 4:3, 11:1, 5). Tohtoročný nález fragmentu vrcholovej kachlice na zámku v Hlohovci má minuskulný nápis ,vis“, čo v priamom preklade znamená silu, moc (obr. 5:4 - za možnost' publikovania d’akujem J. Urminskému).

$\mathrm{K}$ unikátnym renesančným kachliciam z územia Slovenska patrí súbor z výskumu hradu Šariš (kat. Vel'ký Šariš, okr. Prešov). Ide o zeleno glazované kachlice rovnakých rozmerov 

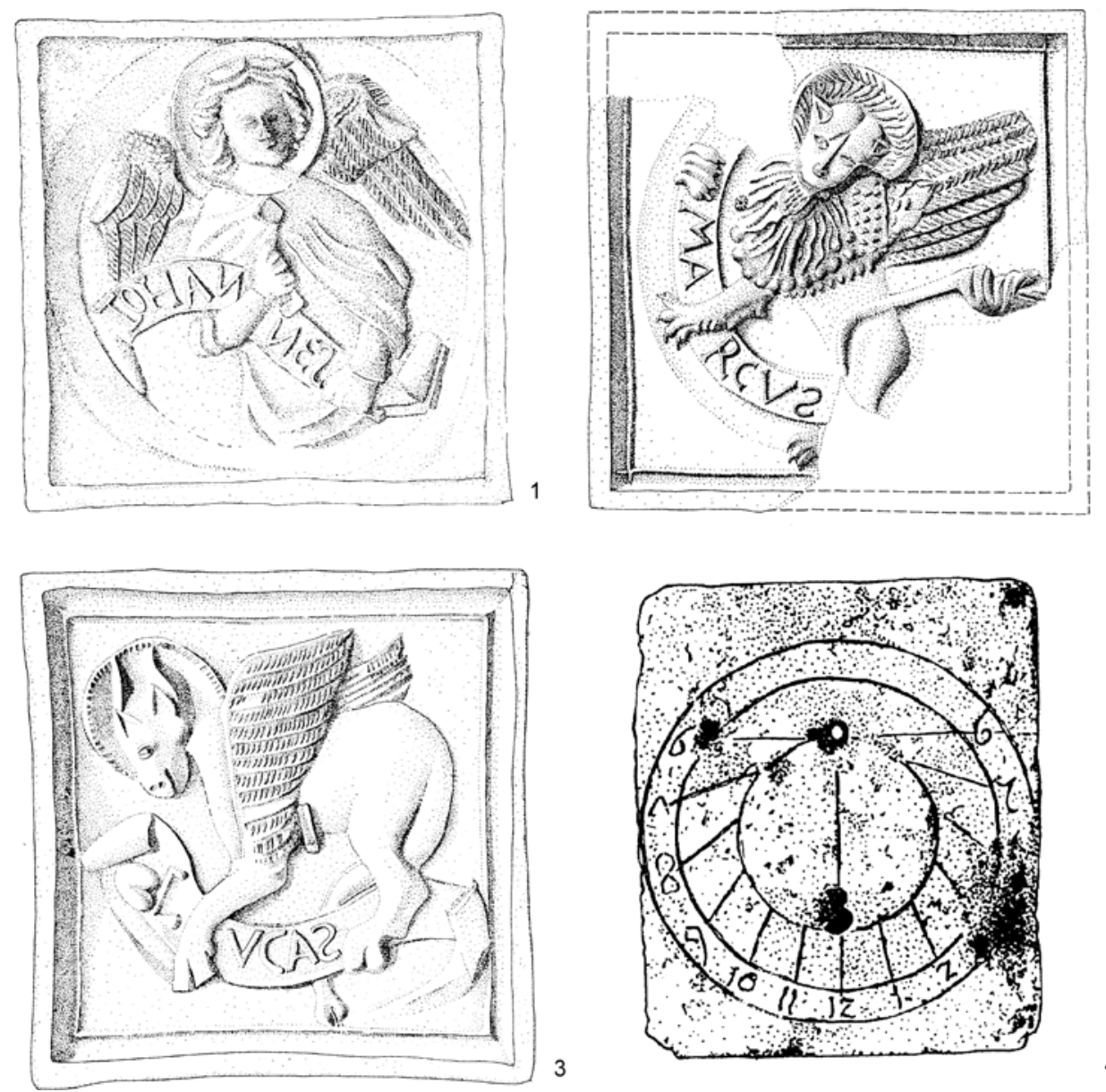

Obr. 6. Letanovce-Kláštorisko. Komorové kachlice s evanjelistami. 1-3 - Ján, Marek a Lukáš; 4 - keramické slnečné hodiny s arabskými číslicami.

Abb. 6. Letanovce-Kláštorisko. Blattkacheln mit den Evangelisten. 1-3 - Johannes, Markus und Lukas; 4 - Sonnenuhr aus Keramik mit arabischen Ziffern.

(25 × 19,5 cm) s vyobrazeniami polpostáv starozákonných králov Dávida, Šalamúna, Nabuchodonozora a sudcu Jepteho, označených majuskulnými nápismi humanistického písma a pri niektorých s vročením 1553 (trojka zrkadlovo obrátená - obr. 7:1-3, 5 a 8:2, 4). Do pece kompozične zapadá aj polovičná kachlica (šírka $9,5 \mathrm{~cm}$ ) s vyobrazením kuželkového stĺpu so zvieratom (obetné tel'a), nad ktorým je nápis PUERI ISRAEL (obr. 7:4, 8:1). „Deti Izraela“ treba u starozákonného Ozeáša $(11,1)$ chápat' metaforicky ako „synov národa“. Obetné zviera personifikuje nevinnost' a pokoru. Polpostavy králov a sudcu sú v arkáde s kazetovým členením oblúka opreté lakt’om o balustrádu, v strede ktorej je nápisový štítok s názvom „hrdinu“ a rokom 1553 (obr. 7:5), resp. rokom nad samotným nadpisovým štítkom (obr. 7:1, 8:2, 3). Súbor predstavuje eklatantný príklad známej norimberskej rytiny, ktorú ilustroval tamojší maliar a rytec Georg Pencz v roku 1531 (Franz 1969, 79, obr. 29; naposledy Loskotová 2012, 664-665, obr. 1, 2). Dodnes zachovaná pec podl'a grafickej predlohy je na cisárskom hrade v Norimbergu (Franz 

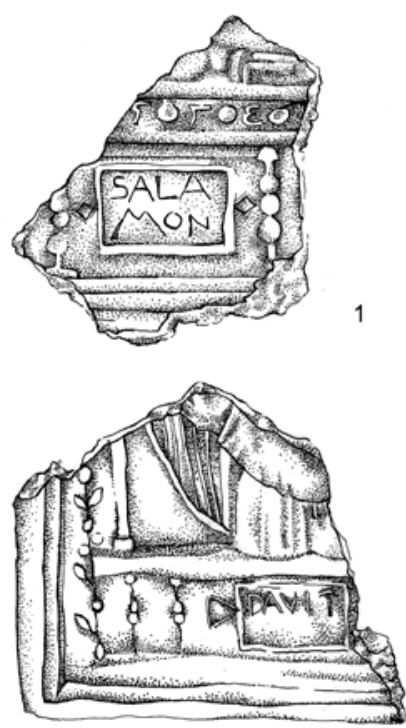

2

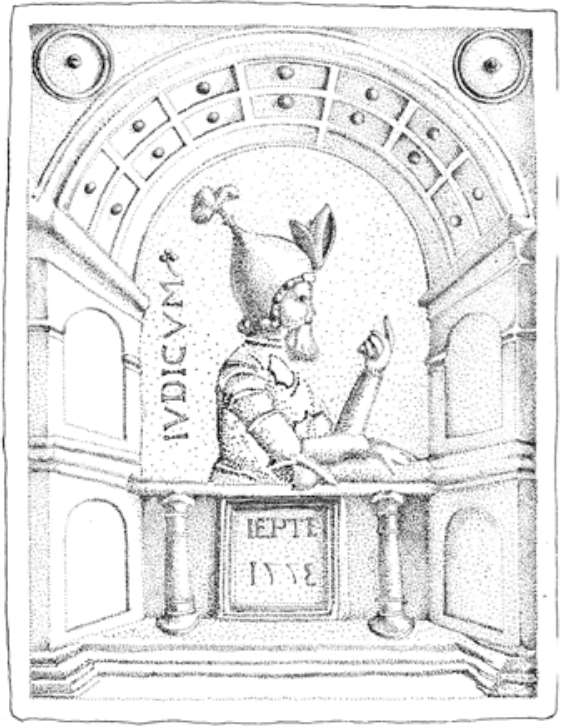

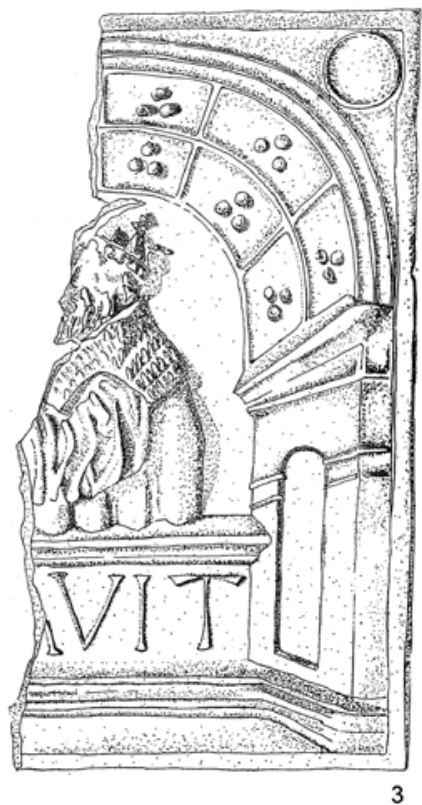

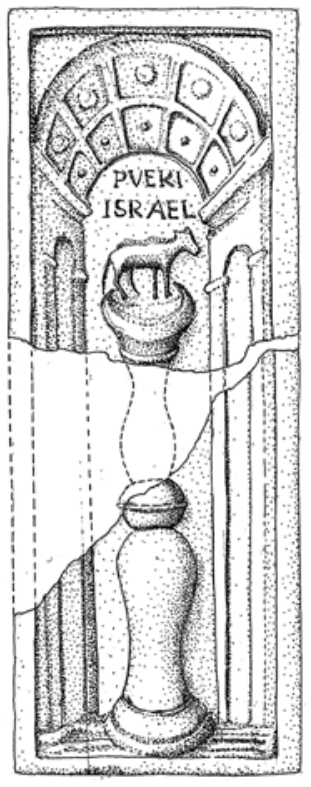

4

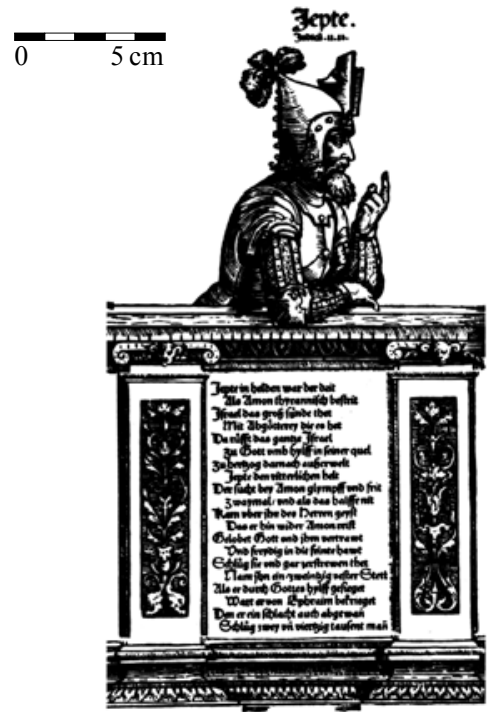

6

Obr. 7. Vel'ký Šariš-hrad Šariš. 1-5 - kachlice so starozákonnými námetmi s vročením 1553; 6 - z rytiny Georga Penczeho z roku 1531 s vyobrazením sudcu Jepteho.

Abb. 7. Vel'ký Šariš-Burg Scharosch. 1-5 - Kacheln mit alttestamentarischen Themen und der Jahresangabe 1553; 6 - aus einem Kupferstich von Georg Pencz aus dem Jahr 1531 mit Darstellung des Richters Jephta.

1969, 79, obr. 191; Holl 1993, 271, obr. 36). V odbornej literatúre im bola venovaná náležitá pozornost', nakol'ko sa ich výskyt rozšíril na širokom teritóriu od Porýnia až do Potisia, ba aj do škandinávskych a pobaltských krajín (Franz 1969; Ose 1992; Holl 1993; Břicháček-Hereit 1996; Ulrychová-Hazlbauer 1998; Loskotová 2012; Tymonová 2012; Žegklitz 2012; Gruia 2013, 

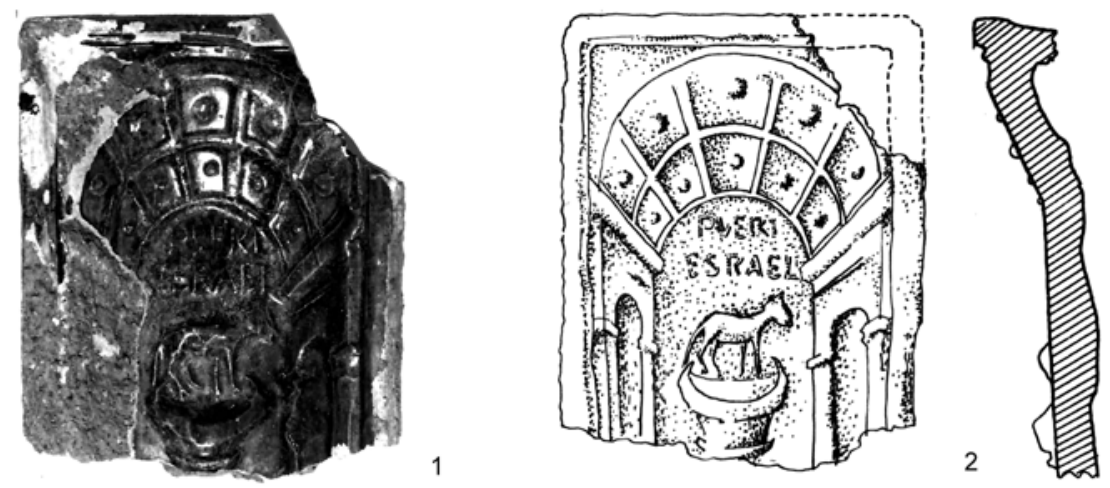

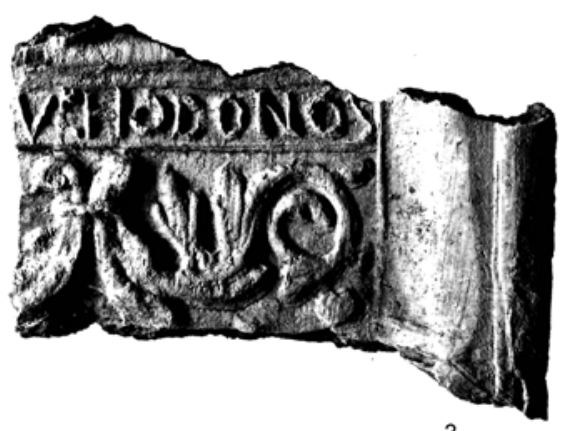

3

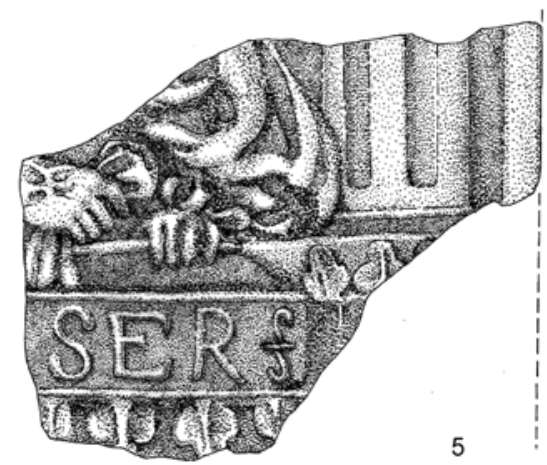

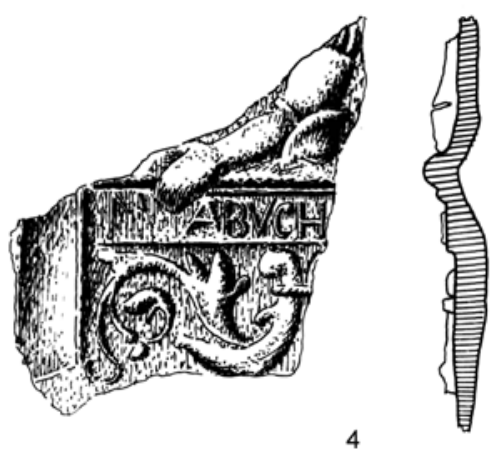

4

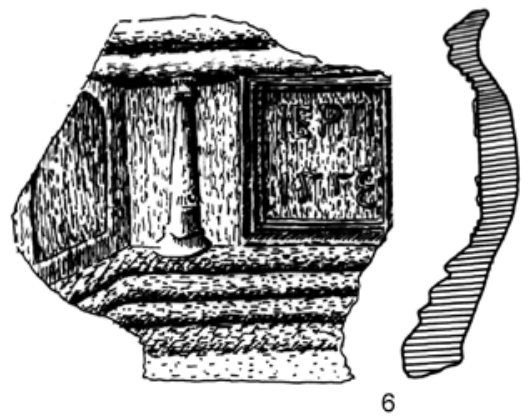

Obr. 8. Vel'ký Šariš-hrad Šariš. Renesančné kachlice so starozákonnými vyobrazeniami a s vročením 1553.

Abb. 8. Vel'ký Šariš-Burg Scharosch. Renaissancekacheln mit alttestametarischen Szenen und der Jahresangabe 1553.

211-213). Ich idea naskrze sledovala reformačný nemecký náboženský prúd. Odev polpostáv je poväčšine v dobovej renesančnej plátovej výzbroji, vrátane prilieb. Najvýznamnejší starozákonní králi Dávid a Šalamún majú však na hlave korunu. Šalamún drží v ruke žezlo - tzv. ríšske jablko s krížikom (obr. 8:2) a Dávid je s atribútom harfy (podl’a biblického vyjadrenia: 1. kniha Samuela 16, 18-23 - pozri Steger 1961, 20, 58 a 129); ide o prototyp krála - inšpirácia panovníkov (Royt 2013, 67-70, 275-277). Na torze kachlice je zachovaný NABUCH (odonozor), ktorý patrí tiež medzi „babylonských hrdinov“, nakol'ko sa ako mladý princ vyznamenal v boji proti egyptskému faraónovi, ako to v Písme opísal prorok Jeremiáš (29). S norimberskou grafickou predlohou akoby splynul sudca Iepte (obr. 7:5, 6) s vyobrazením na kachlici z hradu Šariš, na ktorej je za jeho chrbtom zvisle nápis IVDICVM, čo v preklade - ako na to upozornil 


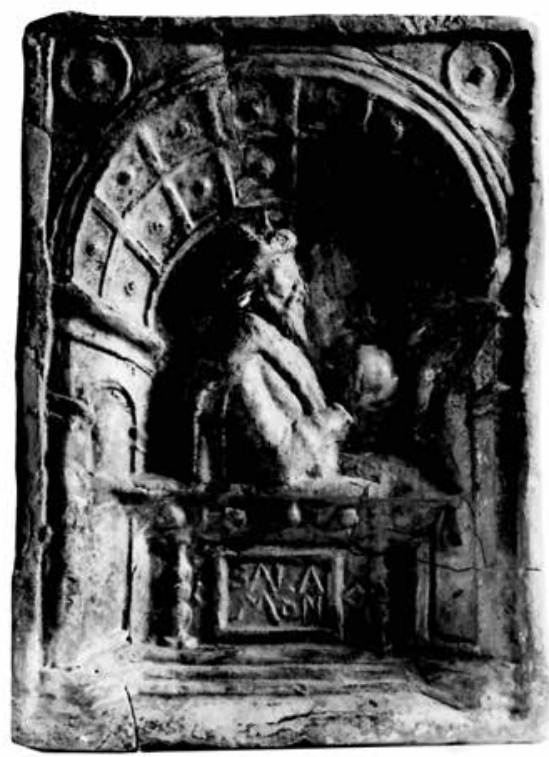

1

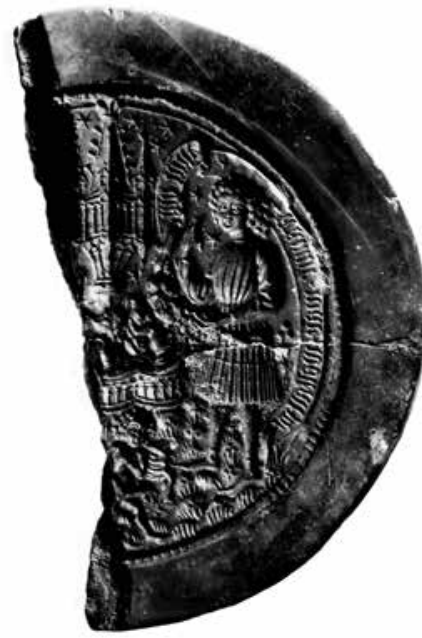

3

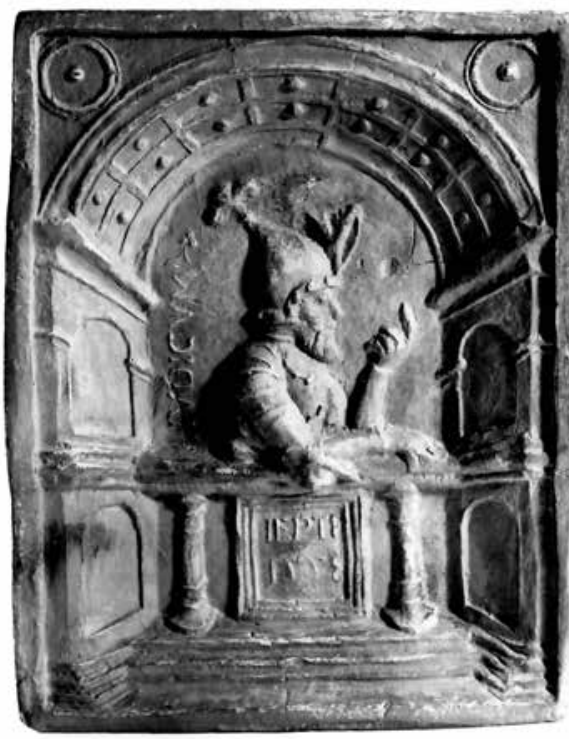

2

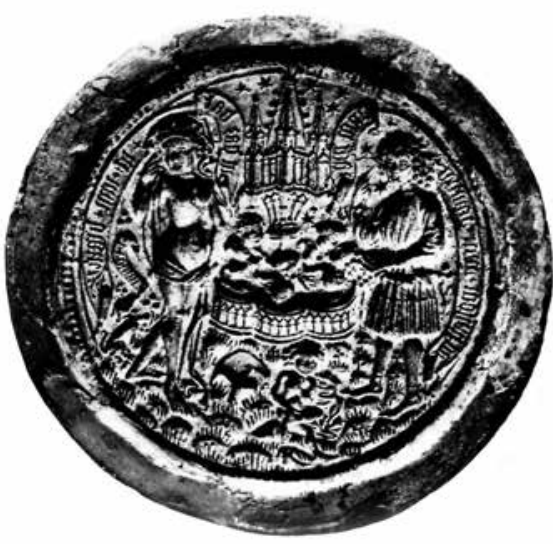

Obr. 9. 1, 2 - Vel'ký Šariš-hrad Šariš, kachlice s polpostavami král’a Šalamúna a sudcu Jepteho z roku 1553; 3 - Letanovce-Kláštorisko, torzo hlinenej formy s motívom tzv. studne lásky; 4 - analogická hlinená forma z Wormsu (podl’a Arens 1971, obr. 81).

Abb. 9. 1, 2 - Vel'ký Šariš-Burg Scharosch, Kachel mit den Halbfiguren König Salomo und Richter Jephta aus dem Jahr 1553; 3 - Letanovce-Kláštorisko, Torso einer Tonform mit Motiv der sog. Schamhaften Liebe; 4 - analoge Tonform aus Worms (nach Arens 1971, Abb. 81).

už Z. Hazlbauer (1998, 641) - znamená „rozsudok či súd“. Názov však označuje biblickú Knihu sudcov vo vzt’ahu k Ieptemu (schopný súdit', rozhodovat'), ako sudcovi Izraela. Podobná kachlica pochádza z meštianskeho domu v Košiciach, v nápisovej tabul'ke je nápis $I E P D$, rok 1571 (?) a za chrbtom polpostavy nápis IVDICIVM (Holl 1993, 267, obr. 31). Ďalšie torzá pochádzajú z hradu Eger, Füzer, Serenča (s rokom 1553) a Boldogkő (Gruia 2013, 211, kat. 2, 49, 57 a 100). Všetky 
fragmentárne zachované kachlice majú v detailoch zhodné vyobrazenia (oblúk kazetového členenia, balustráda) ako na šarišských kachliciach, resp. na náleze z Košíc. To nepriamo napovedá o spoločnej dielenskej výrobe, a to bud' v Košiciach, alebo v Prešove. S Prešovom, ale aj so Šarišským hradom je zviazaný humanistický vzdelanec Juraj Wernher (Werner), pochádzajúci z nemeckej meštianskej rodiny zo sliezskeho Paczkówa. Študoval na univerzite vo Wittenbergu a v Krakove. V Prešove zastával v rokoch 1524-1527 funkciu notára, v roku 1531 sa stal richtárom a rektorom mestskej školy. Od roku 1538 až do svojej smrti v roku 1556 bol kapitánom Šarišského hradu (Balegová 2003). Nakol'ko bol literárne činný a preslávil sa spisom O podivuhodných vodách Uhorska (Bazilej 1549), je pravdepodobné, že grafické predlohy norimberského rytca G. Pencza, ktoré sa stali ilustráciami oslavných veršov Hansa Sachseho Die Erenport, priniesol do Prešova a sám inicioval výstavbu pece. Tento hypotetický predpoklad má svoje logické zdôvodnenie, ked' po vyše dvadsiatich rokoch od vydania Sachseho diela sa ilustrácie (hlavne Iepteho obraz) ako aj celá „reformátorská idea pece“ využili na zhotovenie kachlíc (porovnaj Žegklitz 2012a; Dąbrowska 2013).

$\mathrm{K}$ ojedinelým nálezom patria aj hlinené modely s náboženskými vyobrazeniami, ktorých je $\mathrm{v}$ celoeurópskom meradle známych okolo sto, a to v dvoch prevedeniach: pozitívne a negatívne matrice s nápisovými páskami. V roku 1988 boli pri výskume kartuziánskeho kláštora na Skale útočišta (Letanovce-Kláštorisko) nájdené dva fragmentálne zachované kruhové modely vyrobené zo svetložltej hliny, s vyobrazeniami tzv. prameňa lásky (priemer $11 \mathrm{~cm}-\mathrm{obr}$. 1) a biblického námetu úteku Rodiny do Egypta (priemer $8,8 \mathrm{~cm}$ ). Väčšia matrica má v lícnej časti torza $\mathrm{v}$ dôsledku jeho použitia šedočierne sfarbenie (očadenie). V kruhovo orámovanej časti (forma s priemerom $8 \mathrm{~cm}$ ) je kompozícia obrazu s centrálne umiestnenou fontánou s gotickým nadstavcom a bočnými fialami, po bokoch sú postavy mládenca a neodetej devy (chýbajúca čast') a dopĺn̆a ich nápisová páska v gotickej minuskule so staronemeckým textom: „ach wae frauwe $\cdot$ war wollent yr" (ihr). Vo vol'nom preklade: Ach (vzdychnutie - Ó), vznešená pani, ó, ako túžim po vás (metaforicky: po čistote túžim, v čistote je moja túžba). Pod kadňou je sediaci Amor, ktorý v stredovekej etike predstavuje cnost' (forma virtutum) v pojme lásky k Bohu (amor Dei). Scéna tzv. studne lásky zdanlivo pripomína dobový oblúbený motív erotickej symboliky fontány, známy na nemeckých med’orytinách a v textilnom umení. Pri hlbšej analýze sa javí mariánsky motív, čo nepriamo prezrádza zachovaný nápis a tiež druhý nápis pri neodetej deve, ktorý možno vidiet' na identických formách z Wormsu (Arens 1971, 129, tab. 48) a z Figdorovej zbierky vo Viedni (Walcher-Molthein 1924, 205, obr. 6). Nápis okolo nahej devy: ,in daz bat.ist. min.begir" znamená „do tohto prameňa ma túžba ženie“ (alebo „v kúpeli je moja túžba“, metaforicky: po čistote túžim). Ich produkciu v porýnskej oblasti predpokladal A. Walcher-Molthein, a to aj na základe použitia bielej hliny v okolí Siegburgu, presláveného produkciou hlinených plastík a fajok (Walcher-Molthein 1924, 201, 207-208). Výrobu dnes môžeme pripísat' znamenitému kartuziánskemu majstrovi Jodokusovi Vredisovi (*1473), ktorý pracoval v kláštore vo Wedderne pri Dülmene (vo Vestfálsku) a jeho umelecká činnost' zapadá do obdobia prelomu 15. a 16. storočia (Wormstall 1896; Kosel 2001, 61-62). Preslávil sa aj v kachliarskej produkcii, hlavne výrobou matríc pre kartuziánsky kláštor v Kolíne nad Rýnom. Okrem odlišných nálezov z územia Mad’arska (z královského paláca v Budíne, hradu Köszeg a kláštora Nagyvázsony Holl 1991) je pozoruhodným aj nález pozitívu z červeno pálenej hliny z Olomouca (s priemerom $7 \mathrm{~cm}$ ). Nález pochádza zo zásypu pri mestskej hradbe, stavanej na začiatku 16. storočia, kde mali v tesnej blízkosti svoj rehol'ný dom kartuziáni (Michna 1990, 165, tab. 9:3). Okrúhly model je analogický s naším vyobrazením. Takéto negatívy boli odtlačované aj do vosku a využívané tak ako devocionálie, no hlavne na pečenie perníkov alebo tzv. marcipánov, t. j. markových chlebíčkov (lat. Marci-panis), pečiva z mandlí a cukru.

Do skupiny technickej keramiky patria predovšetkým signované tehly, ktorým sa v poslednej dobe venuje zvýšená pozornost'. Základná katalogizácia značkovaných tehál vykazuje len novoveké nápisy a vročenia (Nagy-Nagyová 2015). Pozoruhodný je nález keramických slnečných hodín z kartuziánskeho kláštora na Kláštorisku (rozmery 22,7 × 18,7 cm, hrúbka $3,8 \mathrm{~cm}$ - obr. 6:4), ktorých ciferník je opatrený arabskými číslicami od 1 po 12 (Slivka 1987). 

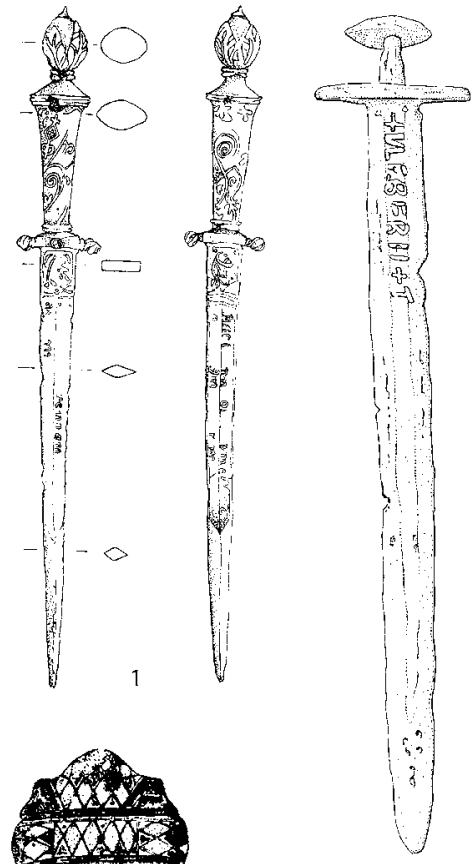

2
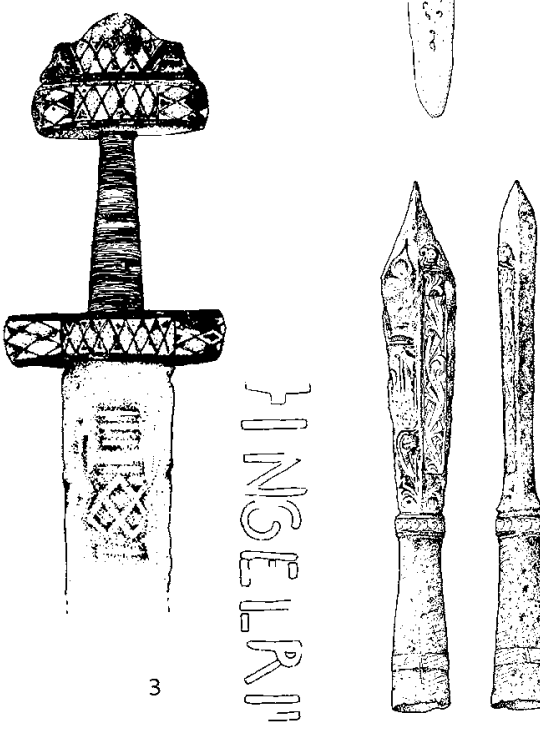

Obr. 10. 1 - Vel'ký Šariš-hrad Šariš; 2 - meč typu Ulfberth zo zbierok rodiny Andrássy v Betliari; 3 - Krásna nad Hornádom, riečny nález meča s nápisom INGELRII; 4 - Smolenice, zdobený ceremoniálny hrot šípu.

Abb. 10. 1 - Vel'ký Šariš-Burg Scharosch; 2 - Schwert vom Typ Ulfberth aus den Sammlungen der Familie Andrássy auf Schloss Betliar; 3 - Krásna nad Hornádom, Flussfund eines Schwertes mit der Inschrift INGELRII; 4 - Smolenice, verzierte Zeremonienpfeilspitze.
Arabské číslice k nám sporadicky prenikajú od konca 14. storočia, no ich duktus je gotický (Trelińska 1991, 217-219; Pátková 2014, 141). Tak je to aj v prípade slnečných hodín, datovaných do poslednej tretiny 15 . storočia. Najstaršie datovanie arabskými číslicami máme na zvone vo veži kostola $\mathrm{v}$ šarišskej dedine Kožany: +14+06 (Čovan 2015, 30). Uvažuje sa aj o chybe zvonolejára, ktorý zamenil 0 a 9 , azda 1496? (Šedivý 2015, 29). Ide o zriedkavý prípad, nakol'ko v epigrafickom materiáli sa s výskytom arabských číslic stretávame skôr po polovici 15. storočia (zvon $\mathrm{z}$ Krušoviec $\mathrm{z}$ roku 1468, náhrobok Juraja zo Schombergu z Bratislavy z roku 1470, nástenné hodiny zo Spišskej Kapituly - porovnaj Prix-Roháček 2009). V celej Európe sa arabské číslice všeobecne uplatnili v 15. storočí, a to - ako uvádza Jean Favier $(2006,306)$ - „,z dôvodu praktičnosti, aj ked' ich všetci použivali s počiatočnou nedôverou".

\section{Zbrane}

V širokej oblasti militárií zaujímajú popredné miesto meče, ktoré $\mathrm{v}$ duchovnej symbolickej rovine predstavujú „osobnost'““ (Jungov archetyp), v Pavlovom biblickom ponímaní ako „meč ducha, ktorým je Božie slovo" (Slivka 2002, 590, 592-593). V tomto duchu a pre ich insigniálny charakter sa niesla samotná produkcia, čo potvrdzujú rôzne inkrustácie znakov a nápisov na ich čepeliach. Doterajšia odborná spisba vykazuje niekol'ko samostatných prác venovaných inskripciám (Wegeli 1902-1905; Ravdonikas 1933; Oakeshott 1964; 1991; Głosek 1973; 1984, 103-121; Głosek-Kajzer 1976; 1977; Wagner-Worley-Holst-Blennow-Beckholmen 2009; Aleksić 2007, 117-126; Košta-Hošek 2014, 282-283; Geibig 1991, 126-127; Lampart 2012; Labuda 2016; parciálne u nás Ruttkay 1971; 1976, 273-287). V poslednej dobe odborný tím zo švédskej univerzity v Uppsale pracuje na dôkladnej analýze nápisov na báze modernej epigrafiky $\mathrm{v}$ celoeurópskom meradle (Worley-Wagner 2013). K najstarším nápisom patria meče s nápismi ULFBERTH, pomenované po ich výrobcovi na strednom Porýní, ktorý žil okolo roku 800 . Z výrobného centra sa šírili do severnej i severovýchodnej Európy v širokom časovom období pod tým istým menom (nápisom, niekedy s prehodenými písmenami) ako značky dobrej kvality (Müller-Wille 1970, 65; Stalsberg 2011). Týmto nápisom je opatrený tzv. svätoštefanský meč, datovaný okolo 
roku 1000 (Ruttkay 1976, 250). Jediný exemplár z územia Slovenska pochádza zo zbierok fondu rodiny Andrássy v gemerskom Betliari. Meč s dížkou 94,6 cm má v hornej tretine čepele nápis ULFBERH-T a je datovaný do prelomu 10. a 11. storočia (obr. 9:2 - Thoma 1993). Do tejto skupiny signovaných mečov po výrobcoch patria aj meče s nápismi INGELRII, ktorých produkcia je doložená v časovom rámci druhej polovice 10. až 11. storočia (súhrne Geibig 1991; Gorman 2005). Nádherný meč s nápisom INGERLII bol v roku 1971 vybagrovaný v riečišti Hornádu pri Krásnej nad Hornádom (obr. 9:3) a je datovaný do druhej polovice 10. storočia (Ruttkay 1975, 152 , obr. 8:2-4, 9, 1976, 282). Ďalší meč s podobným nápisom vyhotoveným damaskovou technikou pochádza z okolia Myjavy (Ruttkay 1971, 163-164, tab. I:1, II a III; 1975, 160, obr. 7:4, 10:3). Forma šošovkovitej hlavice meča, ako aj d’alšieho meča z bližšie neznámej lokality s nápisom INGEILRICENS (v zbierkach Podunajského múzea v Komárne - Ruttkay 1975, 199, obr. 10:2,
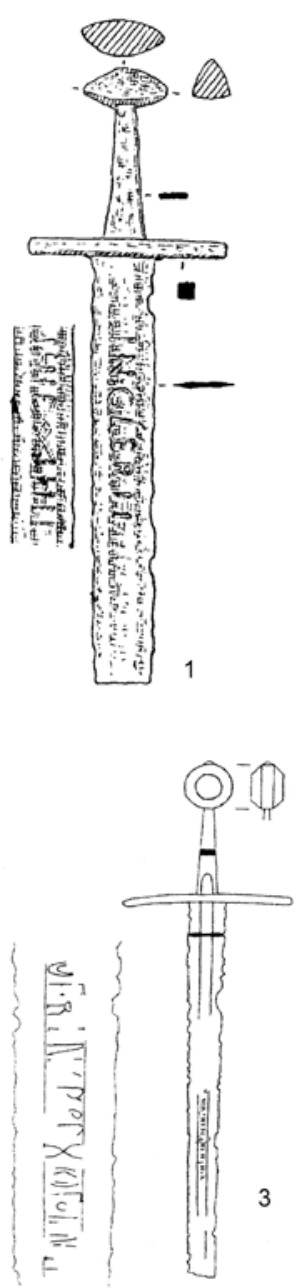
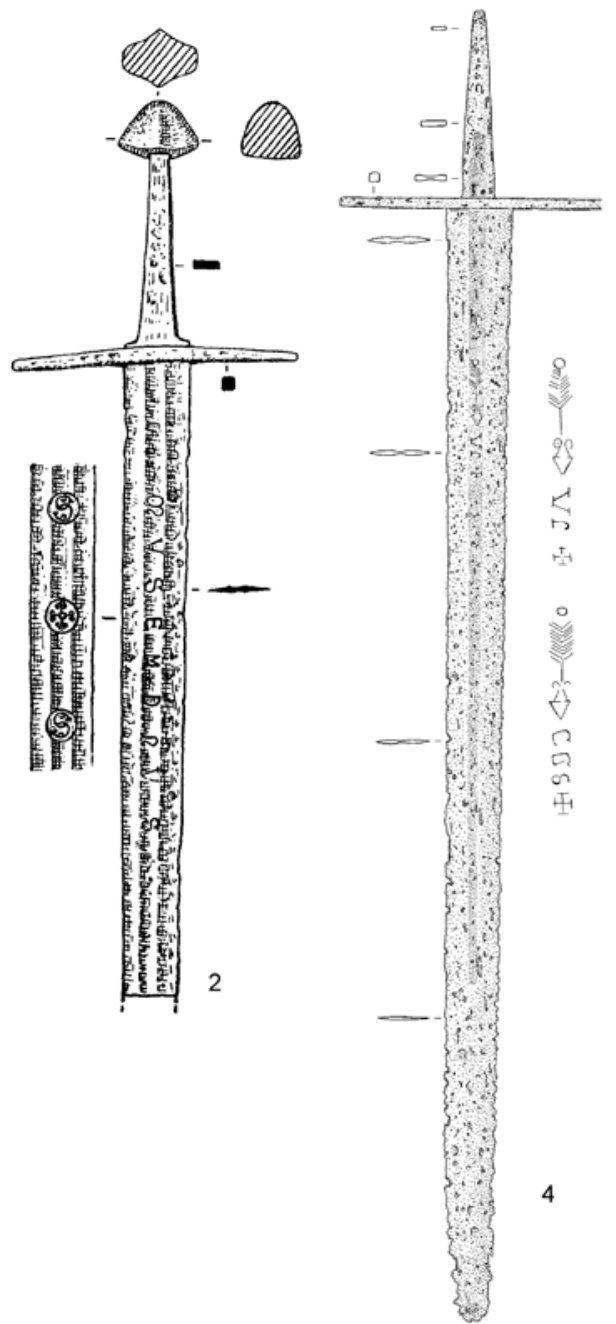

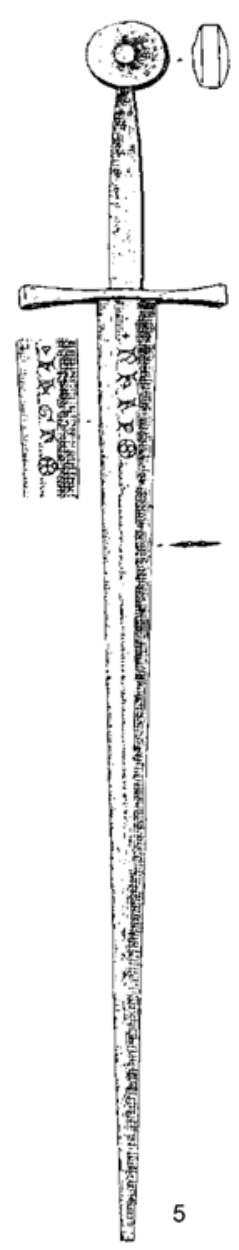

Obr. 11. Meče s invokatívnymi nápismi. 1 - Myjava-okolie; 2 - Husina v Gemeri; 3 - Žehra-Spišský hrad; 4 - Bacúrov, okr. Zvolen; 5 - Kálna nad Hronom.

Abb. 11. Schwerter mit invokativen Inschriften. 1 - Myjava-Umgebung; 2 - Husina in der Region Gemer; 3 - Žehra-Zipser Burg; 4 - Bacúrov, Bezirk Zvolen; 5 - Kálna nad Hronom. 
25:4), sú z mladšieho obdobia 11.-12. storočia (Wegeli 1903-1905, 218-219). Inú skupinu predstavujú meče s nápismi náboženského obsahu, či podl’a M. Głoseka ,s nápismi invokatívnymi““ (Głosek 1973, 57-67; Głosek-Kajzer 1976; 1977). Do tejto skupiny možno zaradit' meč z gemerskej obce Husiná s nápisom MVSEMDNVS (Ruttkay 1971, 164-165, tab. I:2, 1975 145, obr. 2:3, 13:3), u ktorého A. Ruttkay s pravdepodobnost'ou videl skratku MEUS DOMINUS - „,môj Pane“ (Ruttkay 1976, 283; porovnaj Głosek 1973, 57-61, ktorého A. Ruttkay obišiel). Kontrakcia nápisu nastol'uje aj čítanie MEUS EST MAGNIFICUS DOMINUS, t. j. „,môj je velebený Pán“, inšpirovaný slovami žalmistu: „meno tvoje Pane, budem velebit', lebo si dobry““ (Ž 54,8 a 52,11). Na druhej strane čepele sú znaky v tvare gréckeho kríža a dve písmená S. Na nápisy skupiny $S O S$ upozornil už Rudolf Wegeli (1902-1905, 223-224), po ňom Edward Oakeshott (1964, 142, obr. 132) a M. Głosek $(1973,66-67,1984,111)$, čo by znamenalo „Salvator Omnipotens Salvator“, teda „Spasitel' všemohúci záchranca“" (niekedy iba S.O.-sancti offici-svätá služba). A. Ruttkay interpretuje nápis ako „Salus Omnium Salus“ (Ruttkay 1978, 63). Novší nález meča zo Serede - hradu Šintava - má na obidvoch stranách znaky vo forme písmena S, po stranách s gréckymi krížikmi a na druhej strane čepele sú dve písmená S, zvierajúce krížik. M. Labuda (2016, 65-67) ho datuje do prelomu 12. a 13. storočia a vidí v ňom paralelu, pričom chýbajúce písmeno O nahrádza berlový kríž. Môže však íst' o skratku „sanctus“, čo v latinčine znamená aj Stvoritel’ (Traube 1907, 193).

Ďalší meč z neznámej lokality sa nachádza vo Vlastivednom múzeu v Galante, na oboch stranách jeho čepele sú značky vyplnené žltým kovom (mosadzou). Dve písmená D a B, v strede zvierajúce grécky krížik a na druhej strane tri a štyri zvislé čiary zvierajúce krížik v kruhu (Labuda 2016, 81-83, obr. 75, 78). Pravdepodobne ide o začiatočné písmená $B$ (enededictus) $D$ (eus) - Požehnaný Boh, a na druhej strane kristocentrika, zdôraznená siedmimi zvislými nožičkami, akoby označujúcimi Jeho dokonalost' (Forstner 1990, 47). Meč je datovaný do polovice 12. storočia a zapadá do skupiny mečov „Benedictus“ (Głosek-Kajzer 1976; 1977).

Iný románsky meč bol prednedávnom nájdený pri obci Bacúrov (okr. Zvolen), na čepeli má abreviačný nápis: $+S J J+J A$ (obr. 10: 4). Autori publikovaného meča ho interpretujú ako „,začiatočné písmená latinského zvolania: $\mathrm{S}$ (alvator) $\mathrm{J}($ esus) $\mathrm{J}(\mathrm{esus})$ a $\mathrm{J}(\mathrm{esus}) \mathrm{A}(1 \mathrm{tissimi})$ ? - v preklade ,Spasitel', Ježiš, Ježiš a Ježiš Najvyšší(?)““ (Čambal-Choma 2010, 115, tab. II). Litery majú unciálový charakter románskej doby (meč je z 13. storočia), pričom prvé tri písmená môžu byt: $\mathrm{S}$, obrátené D?, otočené C, t. j. +S(anctissimus) D(eus) C(aelestis) - I(esus) A(eternum) - Najsvätejší Bože nebeský, Ježiš večný (nesmrtel’ný), pričom krížiky invokujú „,v ich mene“ (In nomine).

V sledovanom kontexte je problematický vodný nález meča v Kalnej nad Hronom s nápisom RHAP a v symetrickom kruhu s písmenom $\mathrm{S}$. Na opačnej strane čepele je unciálna forma VDGN s krížikom v kruhu (Ruttkay 1975, 148, obr. 7:1, 13:4; obr. 10:5). A. Ruttkay datoval meč do 13. storočia $(1975,165)$ a M. Głosek $(1984,117,121$ v pozn. 117) až do polovice 14. storočia, konštatoval: ,že litery sú len fragmentárne zachované“, a tak nedovol'ujú vyjadrit' jednoznačnú lektúru; podobne ho neinterpretuje ani Aleksić (2007, 121). Len s istou dávkou odvahy by sme nápis čítali ako „Radix habemus animae ad praelium“ - vychádzajúci z Dávidovho žalmu 143,1: „Pane, vyslyš moju modlitbu, (...)“. Súdobý meč bol v roku 1967 vybagrovaný v rieke Trebel v nemeckom Bassine. Má podobnú skratku $D V G N$ a $D I G N$, a je označený tzv. pasovským vlkom a jednorožcom (Schoknecht 1969, 213, 215, obr. 1:b, 2:b). Skratková forma azda poukazuje na istú vznešenost' - DU(lcis) Granditas DIGN(itas). Meče z pohl'adu ich dobového deponovania vykazujú v celoeurópskom meradle rovnaké nálezové okolnosti, a to jednak ako hrobové nálezy vtedajších elít,t. j. ako symbol moci, zriedkavo na hradoch (napr. Spiš), výhradne v ich reprezentačnej alebo ceremoniálnej funkcii, a potom (poväčšine) ako tzv. vodné (riečne alebo jazerné) nálezy. Tento depozičný kontext bol zámerný, podmieňovaný vierou,t. j. ako „zbran̆ darovaná posvätnej vode“ (Torbrügge 1970-1971, 123).

Iné exempláre sú známe len zo zbierkových muzeálnych fondov, ktoré pôvodne možno rovnako zaradit’ do vyššie spomenutých „depozitov“. V zbierkach Východoslovenského múzea v Košiciach sa nachádza meč (zachovaná dížka $72,8 \mathrm{~cm}$ ) s nápisom NR.A IA IAINI., datovaný do prelom 12. a 13. storočia (Głosek 1984, 141-142, tab. IV:55). Centrálne miesto v nápise 
zaujíma litera I, pričom nápis je azda iniciálneho charakteru a je t’ǎké ho interpretovat'. Radí sa do skupiny mečov s nápisom INIINI, ktorých čítanie popredný odborník M. Głosek pripúšt’a aj sprava dol'ava (Głosek 1984, 107): I(esus) N(azarenus) I(esus) A(eternus) opakovanie IA A(ltissimi) R(ex) N(oster), t. j. Ježiš Nazaretský, Ježiš večný, Ježiš nesmrtel'ný, Ježiš Najvyšší (resp. altus - vznešený) náš král'. Invokácia majstra je tak upretá na všemohúci majestát Krista ako „král'a vekov“ (1Tm 1, 17, Zj. 22, 5).
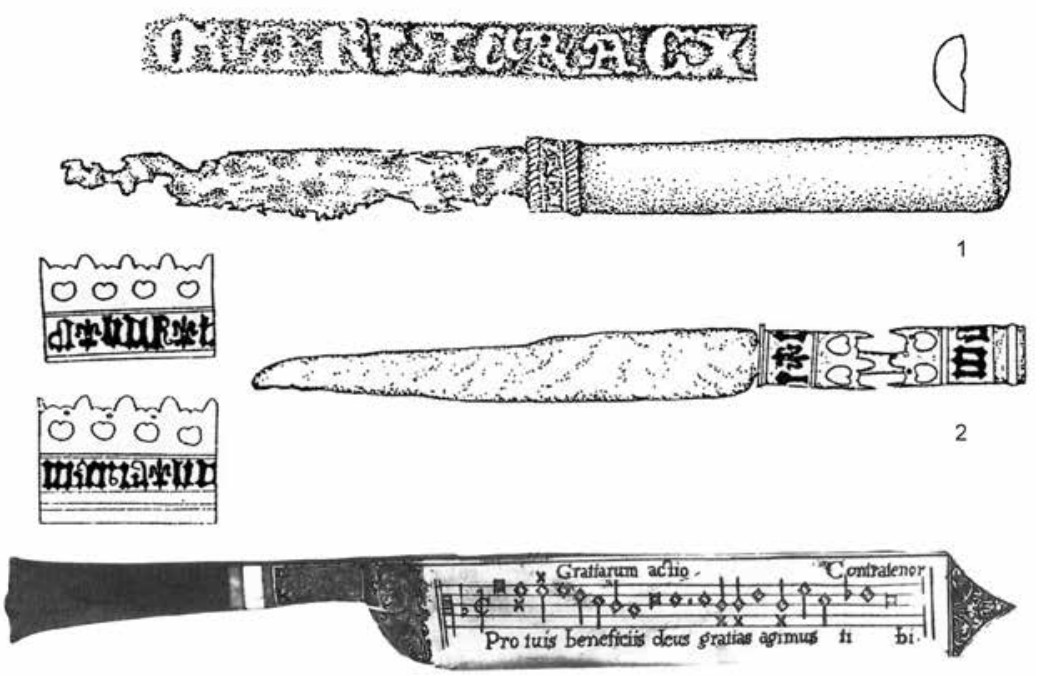

3
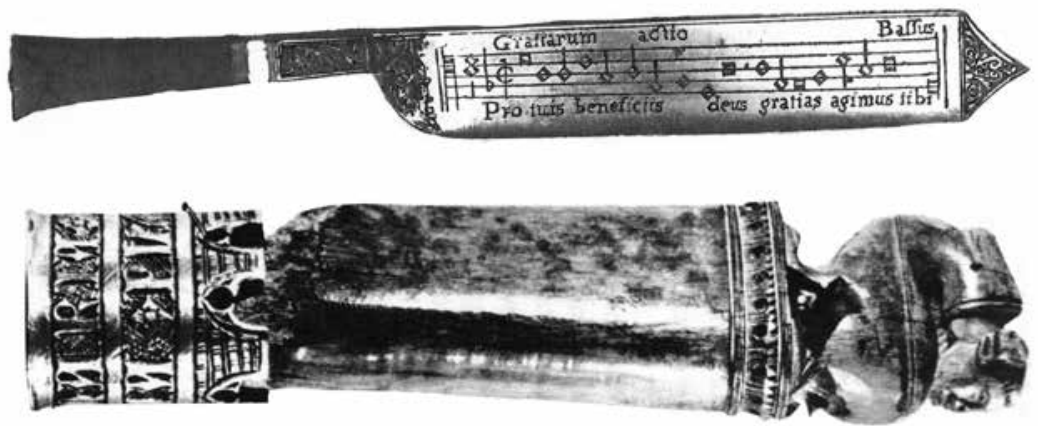

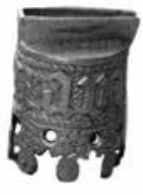

5

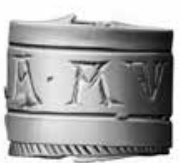

6

Obr. 12. 1 - Banská Štiavnica-Staré mesto; 2 - Ruská Nová Ves - hrad Solivar; 3 - Musée de Cluny, Paríž, nôž bližšie neznámeho kláštora (podl’a Laurioux 1999, obr. na s. 26); 4 - Stary Szącz v Malopol'sku, kláštor klarisiek (podl’a Wachowski 2013, obr. 31:a); 5 - Szczecin; 6 - Fuchsenhof, Horné Rakúsko.

Abb. 12. 1 - Banská Štiavnica-Altstadt; 2 - Ruská Nová Ves - Burg Solivar; 3 - Musée de Cluny, Paris, Messer eines nicht näher bekannten Klosters (nach Laurioux 1999, Abb. auf S. 26); 4 - Stary Szącz in Kleinpolen, Klarissinnenkloster (nach Wachowski 2013, Abb. 31:a); 5 - Stettin; 6 - Fuchsenhof, Oberösterreich. 
Posledný signovaný meč z prelomu 13. a 14. storočia pochádza z archeologického výskumu Spišského hradu so značne poškodeným nápisom (obr. 10:3). Odborne ho len prednedávnom vyhodnotil Filip Lampart (2012). Podla jeho čítania má nápis litery OERIN...XO (?) ...NI..., čo autor len hypoteticky interpretuje vo význame „Omnipotens Eterne Rex Iesus Nazarenus... Christus Omnipotens Eterni Nostri“ (Lampart 2012, 131; ... Christo Nostris aeternus).

Zo skupiny bodných zbraní je zastúpený nález celokovovej dýky zo Šarišského hradu, ktorú nálezca (detektorista) neodborne ošetril od korózie, čím poškodil miniskulový nápis na obidvoch stranách čepele (obr. 9:1). Na základe prvého čitatel’ného slova „alle“ a „um“ sa dá na nej predpokladat' nemecký text. Podl'a zdobenej cylindrickej rukoväte a štylizovanej priečky, zakončenej tordovanými hlavičkami sme ju datovali do prvej polovice 16. storočia (Slivka 2003). Dýka pravdepodobne pochádza z dolnonemeckých dielní (Ullmann 1961, 12).

S nápismi sa stretávame aj na kopijach (Žákovský 2008), ale aj na výstroji (známe prilby z Anglicka), hlavne z Yorku (Tweddle 1983; Guerra 2008, 63-72, 137-139, obr. 27:1-3), na neskorostredovekých ceremoniálnych ostrohách zo zbierkových muzeálnych fondov v Prahe, Budapešti, Levoči (Denkstein 1969) a v Krakove (Pela 2008, 197-199). Zo Smoleníc pochádza hrot železného šípu (dĺžka 12,5 cm), zdobeného intarzovanou rastlinnou ornamentikou a s nečitatel'ným písmenom gotickej minuskuly na tul'aji (obr. 9:4). Nález pochádza zo súkromnej archeologickej zbierky regionálneho historika - rímskokatolíckeho kňaza Pavla Jedličku, ktorý po teologických štúdiách začas pôsobil (pred rokom 1870) v Budíne. Tamojší vojenský historik J. Szendrei mal tak možnost' nález zdokumentovat'. Prvý ho aj publikoval a datoval do 15. storočia (Szendrei 1896, 137-138, obr. 353). Tento hrot neušiel pozornosti ani J. Kalmárovi (1957, 155, obr. 31c), ba ani H. Nickelovi (1969, 106, obr. 26), no v čase publikovania ho posledne menovaný považoval „za nezvestny“ (verschollen). Jedličkovu zbierku dnes opatruje Západoslovenské múzeum v Trnave, kde sa hrot nachádza (i. č. 651 - Novotný-Fuhrherr 1971, 13, 36, obr. 2). Najnovšie sa mu venoval A. Ruttkay, ktorý ho však mylne datoval do druhej polovice 14. storočia (Ruttkay 1978, 62, 106, obr. 34) a vylúčil možnost' jeho praktického použitia pri strel'be. Podl'a neho ho mohol používat' velitel' streleckého cechu, ako na to upozornil už J. Kalmár, resp. slúžil ako ceremoniálny odznak (Kalmár 1957, 164). Z Moravy pochádza jediný takýto hrot z tvrdze Mstěnice, opatrený gotickým monogramom „A“, ktorý V. Nekuda interpretoval ako monogram českého král’a Albrechta (1437-1439), tak ako už predtým V. Nickel (Nekuda 1985, 146, obr. 200; Nickel 1969, 127, 130).

Medzi zbrane často zarad'ujeme i nože, ktoré v symbolickej kategorickosti predstavujú nešl'achetnú - zákernú zbraň (Slivka 2002, 590). Luxusné exempláre mali rukoväte vyhotovené z kostených obložení rôznej dekorácie alebo z vyrezávaných antropomorfných, prípadne zoomorfných figuriek (Holtmann 1993, 294-195). O ich využití pri stolovaní svedčia viaceré stredoveké vyobrazenia - zrejme podl'a spoločenského postavenia, zvykov a výchovy (Elias 1980, 110-111; Holtmann 1993, 541-568). Do tejto skupiny možno zaradit' i nože, ktoré na predele rukoväte a čepele zdobí strieborná prstencová objímka s nápisom gotickej majuskuly „Maria gratis“ (Mária vd’aka), aký poznáme zo Starého mesta v Banskej Štiavnici (obr. 12:1 - Labuda 2000, 22, obr. 9:10). Analogická strieborná objímka, ale s nápisom AVE.MARIA pochádza z vel'kého pokladu z dolnorakúskeho Fuchsenhofu, objaveného v roku 1997 (obr. 12:6 - Prokish-Küthreiber 2004, 320, 654-655, obr. 354). Unikátna je rukovät' noža s prstencovou objímkou typu $A V E$ MaRIA z kláštora klarisiek v malopol'skom Starom Szączi (obr. 12:4), ako i d’alšie mosadzné objímky s nápismi z Vroclavi a Szczecina (obr. 12:5 - Wachowski 2013, 88-89, obr. 31:a, d, e). Ďalší, pomerne dobre zachovaný nôž bol nájdený na hrade Solivar pri Prešove (obr. 12:2 - Tomášová 1999, 177, tab. VII:2). Rukovät' na obidvoch koncoch zdobia mosadzné prstencové objímky s minuskulným opakujúcim sa nápisom „maria“ v predelení tzv. anjuovskej l’alie, ktorá ju tiež len symbolizuje. Invokácie vo svojej koncentrovanej forme mariánskej úcty a chvály nesú v sebe prvú čast' modlitby „Zdravas“ (doslovne Raduj sa) Maria (Weismayer 1994, 105; Petri-Beinert 1996, 397-382), čo je biblického pôvodu (Lk 1, 8 a 42). Možno sa len domnievat', že takéto nože s nápismi slúžili iniciatívnemu účelu pred započatím stolového hodovania. V Musée de Cluny v Paríži sa nachádza nôž z kláštorného reflektára, ktorého čepel' je opatrená notovým d’akovným 
hymnom. Jeho text dobrodenia „Gratiarum actio pro tuis beneficiis deus gratias, agmus tibi“ (obr. 12:3) svedčí o tom, že pri jedení mnísi d’akovali Bohu za jeho každodenný chlieb. Unikátny nôž je talianska práca zo 16. storočia (obr. 12:3 - Laurioux 1999, obr. na s. 26; Sonntag 2008, 322). Naše exempláre sú z 15 . storočia a v stredoeurópskych publikovaných nálezoch sme $\mathrm{k}$ nim nenašli d’alšie analógie.

\section{Kl’úče}

K nepovšimnutým nálezom v literatúre patria neskorogotické kl'úče s obvykle zdobenou kruhovou hlavicou, vyplnenou iniciálnymi písmenami A, V a P (obr. 13). Z nich jednoznačne možno v litere P vidiet' apoštola sv. Petra, ktorému Kristus zveril „kl’úče od nebeského král'ovstva“ (Mt 16, 18-19; pozri Köhler 1905; Brinkhann 1936). Ojedinelý nález malého kl'úča sa nachádza v zbierkach Mad’arského národného múzea v Budapešti (obr. 13:5) a F. Temesváry
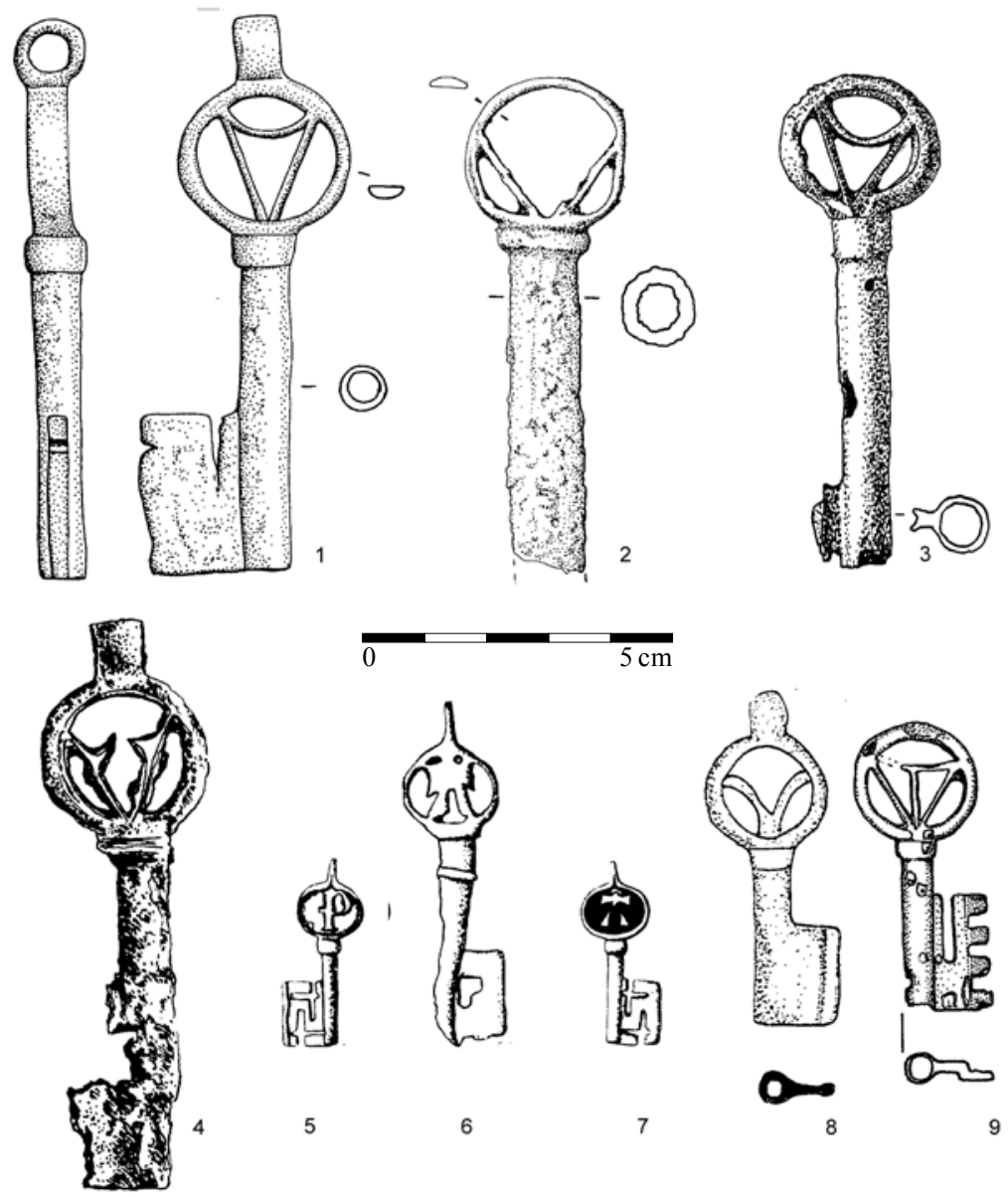

Obr. 13. Železné kl’úče z 15. storočia opatrené iniciálkami. 1-3 - Letanovce-Kláštorisko; 4 - Mstěnice na Morave (podl’a Nekuda 1985, obr. 212:k); 5-7 - zo zbierok Mad’arského národného múzea v Budapešti (podl’a Temesváry 1961, obr. 49:12-14); 8 - Ruská Nová Ves - hrad Solivar (podl’a Tomášová 1999, tab. X:5); 9 - Kuchyňa-Zámeček (podl’a Farkaš 2015, obr. 12). Abb. 13. Mit Initialen versehene Eisenschlüssel aus dem 15. Jahrhundert. 1-3 - Letanovce-Kláštorisko; 4 - Mstěnice na Morave (nach Nekuda 1985, Abb. 212:k); 5-7 - aus den Sammlungen des Ungarischen Nationalmuseums Budapest (nach Temesváry 1961, Abb. 49:12-14); 8 - Ruská Nová Ves - Burg Solivar (nach Tomášová 1999, Taf. X:5); 9 - Kuchyňa-Zámeček (nach Farkaš 2015, Abb. 12). 
ho datoval do 15. storočia (Temesváry 1961, 163, obr. 49:12). Vel’a dokladov v ich atribútovom vyjadrení je na stredovekých vyobrazeniach (Linlaud 2014, XVII-XXI, 121-146) a nachádzame ich aj na neskorogotických kachliach (Banská Bystrica, Fil’akovo, Trebišov - Gruia 2013, 56-57, kat. č, 227, 236; Kalmár 1959, 25, tab. XLIV:5; Slivka 1981, 237, obr. 8:6). Klúče majú mnohoraký symbolický význam (otváranie brán podsvetia - hrobové nálezy) v náboženských predstavách a ceremóniách. V rakúskom cisterciánskom kláštore sa od roku 1479 konal tzv. Schlüsselfest (9. novembra), ked' bola brána kláštora otvorená aj laickej verejnosti (Wolf 1956, 57-59). Rovnako aj pri odovzdaní moci alebo pri predaji majetku (Waidacher 1965, 11-13; Forstner 1990, 398-400; Mandel 1993, 149-150; Lurker 1998, 99-100; Linlaud 2014, 147-151). V teologickom zmysle je kl'úč cnost’ou viery, t. j. dobrovol'ného aktu k otvoreniu samého seba. Azda $\mathrm{v}$ takomto kontexte, ale hlavne $\mathrm{v}$ biblickej podstate možno interpretovat' častejší výskyt kl'účov s označením „A“ alebo „V“. Kl'úč otvára, teda všeobecne sprístupňuje (Vulgo) brány, metaforicky bránu pravého poznania Pravdy (Veritas), ale tiež metafora Kríža ako klúča (Kobielus 2000, 172-176). Ježiš povedal zákonníkom: „Beda vám, zákonníci, lebo ste vzali klúúc poznania!““ (Lk 11, 52), t. j. nechali ste bránu pravého poznania (Agnitio) Bohu uzamknutou. V Zjavení Jána $(1,8)$ je Božia večnost' označená Alfou a Omegou, t. j. začiatok i koniec. Kl'úče tohto označenia máme hlavne z kláštorného prostredia (Kláštorisko) z pohl’adu závesného uška (obr. 13:1-3), ale aj z viacerých hradných objektov: Kuchyňa - obr. 13:9 (Farkaš 2015, obr. 12), Solivar - obr. 13:8 (Tomášová 1999, 186, tab. X:5), Hrabušice - Marcelov hrad (Polla 1962, tab. V:16), Rokštejn (Měřínský 2007, obr. 59:9), Vizmburk (Hejna 1983, obr. 4:5), Sion (Jánská 1965, 37, obr. VII:4, tab. VIII:4), d’alej zo Mstěníc - obr. 13:4 (Nekuda 1985, 158, obr. 212:k) alebo zo Sezimovho Ústí (Krajíc 1991, 333, obr. 15:15). Svojou vel'kostou a dutým driekom poukazujú na to, že sa používali na uzamykanie skrín alebo truhlíc s cennostami, prípadne mrežových postofórií (Mandel 1993). Sakralita litier má aj na tomto druhu pamiatok svoje opodstatnenie, a nie je to len gotický ozdobný prvok. V nemeckom Porýní sa v staršom karolínskom, ale aj otonskom období vyskytujú bronzové kl'úče s hlavicou zdobenou vo forme rôzneho krest’anského kríža, ba mladšie exempláre $\mathrm{z}$ Litvy majú kvadratickú bradu opatrenú $\mathrm{v}$ tvare gréckeho kríža a v nárožiach so štyrmi dierkami (Koch 2012, obr. 1, 2; Schulze-Dörrlamm 2012, 195-196, obr. 4, 6, 7). Typ je známy aj na ranostredovekých miniatúrach a spája sa so symbolom Krista ako Salvator mundi (Schulze-Dörrlamm 2012, 201, obr. 8). Ako devocionálne predmety ich pútnici prinášali z Ríma, teda od hrobu sv. Petra, a tak poslúžili (hlavne ženám) ako hrobová príloha k večnému odpočinku (k symbolike uzamknutia pozri Wachowski 2013, 102-106). V európskych monografických spracovaniach kl'účov a zámkov sme k našim kl’účom nenašli paralely (Raffaelli 1996; Prochnow 1966; Pankhofer 1974; Mandel 1993; Linlaud 2014; Westphalen 2002, 170-171, tab. 67-69; Ottaway-Rogers 2002, 2861-2879). Tiež sa často umiestňovali v kostoloch do sakristie alebo do ich veží, a opatroval ich thesaurarius ecclesiae ako kl'účový nosič (claviger, archievalis) či opatrovník“ (Köhler 1905, 221).

\section{Sklenené poháre}

V slovenskom nálezovom fonde majú ojedinelé zastúpenie aj sklenené poháre s rytými nápismi. Známe sú zatial' len z dvoch lokalít - z Bratislavy a Banskej Bystrice. Pri výskume tzv. Vodnej veže v Bratislave bol v zásype studne nájdený nízky pohár (výška $8,2 \mathrm{~cm}$ ) s rytým dekorom a štyrmi nápismi s menami rodín Khamper M Linggahol, Georg Vitt(e) $l$ a Gruenberg a s vročením 1569 (obr. 14:1). V publikovanom čítaní nápisu (Sedláčková a kol. 2016, 51, 122, obr. 67) sú i d’alšie písmená „,WmB v.s.w“; pri našom osobnom čítaní je „G.m.B. v.s.w.“, čo by predstavovalo iniciálky troch král'ov: Gašpar, Melichar a Baltazár. V mestskom jadre v Banskej Bystrici sa v odkrytom renesančnom dome (v roku 1995) našli zlomky neúplného kónického pohára (zach. výška 7 cm) s rytými nápismi: „AN...SEI 159(?) SEP(g) Bansis Byztric?““ (obr. 14:2 Mácelová 2009, 31-32, obr. 1). Obidva renesančné poháre si zaslúžia hlbšiu historicko-paleografickú analýzu a pravdepodobne poslúžili na iniciačný rodinný (svadobný alebo krstný?) obrad (porovnaj Štajnochr 1998). Ak je náš dešifrát písmen G.m.B. správny, tak sa pohár používal 
na sviatok Epifanie (Zjavenia Pána) na podávanie svätenej trojkrálovej vody (Štajnochr 1998, 39). Je všeobecne známe, že mená Troch králov mali v stredoveku ochranný charakter pred všetkými nebezpečenstvami. V čase Epifanie sa na dverách príbytkov kriedou označovali ich iniciálkami C+M+B (Franz 1909, 266-267, 505). Slová sa tak stali univerzálnym antidotom pred všetkým zlom i chorobami (Bracha 1991, 30-31). Nasvedčuje tomu aj okrajový nápis na pozlátenej čaši z mad’arského Körmendu, datovanej do 15. storočia (Vattai 1956, 70, obr. 2, tab. XI:2), prípadne aj na zvonoch ako traja „Páni počasia“ (Wegeli 1902-1905, 292). Dokladom je aj unikátna kováčska práca dverí z premonštránskeho kláštora v Lelesi, ktoré boli pôvodne osadené pri vstupe do miestnosti archívu či klenotnice nad sakristiou (dnes vo Východoslovenskom múzeu v Košiciach - obr. 15:3) Zlátené kosoštvorcové polia železného kovania vypíňajú písmená gotickej majuskuly. T. Lehoczky nápis dešifroval a publikoval v roku 1871: „Obnovené roku spásy 1400 Dominikom, ctihodným prepoštom leleského kláštora sv. Kríža, na počest' Gašpara, Melichara a Baltazara“ (Lehoczky 1871, 278-279, obr. 4). Mená troch králov mali mat' apotropaický účinok

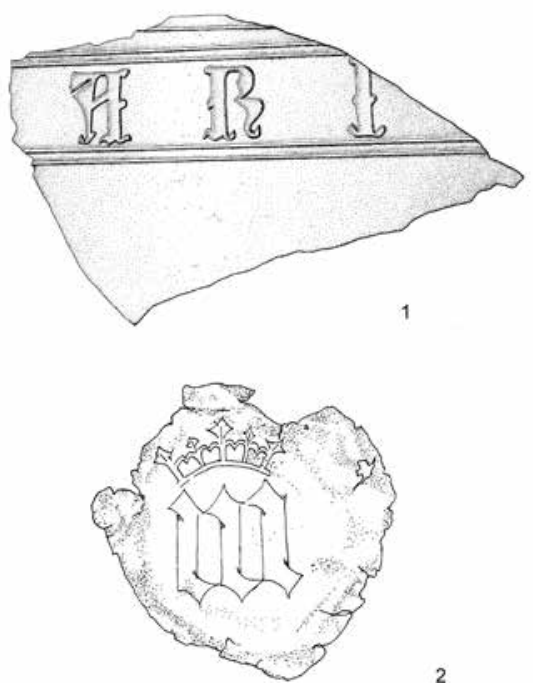

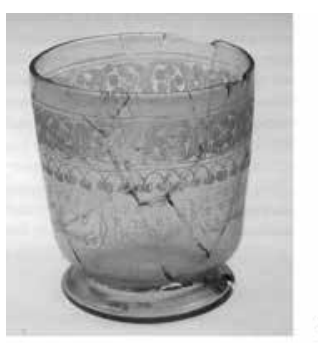
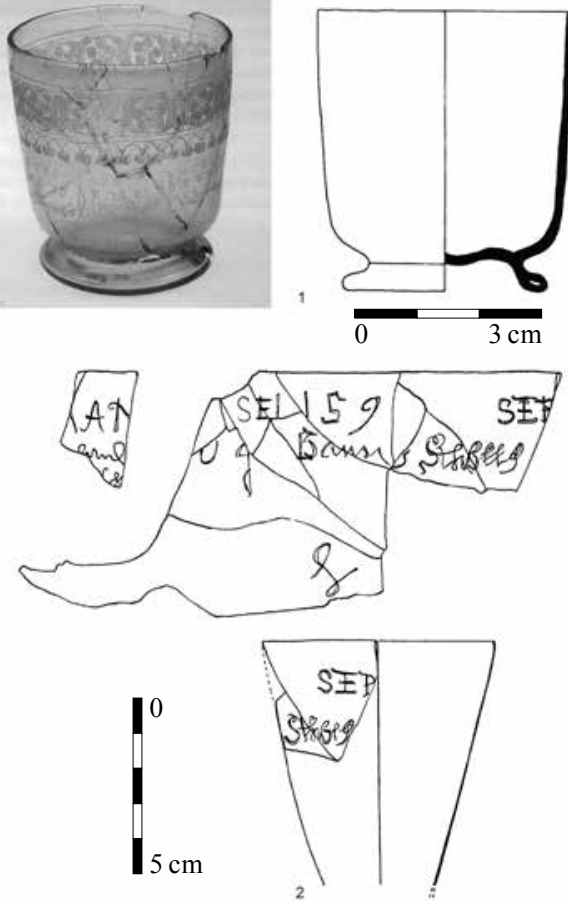

Obr. 14. Sklenené poháre s nápismi zo 16. storočia. 1 - Bratislava - Vodná veža; 2 - Banská Bystrica.

Abb. 14. Glasbecher aus dem 16. Jahrhundert mit Inschriften. 1 - Bratislava - Wasserturm; 2 - Banská Bystrica.

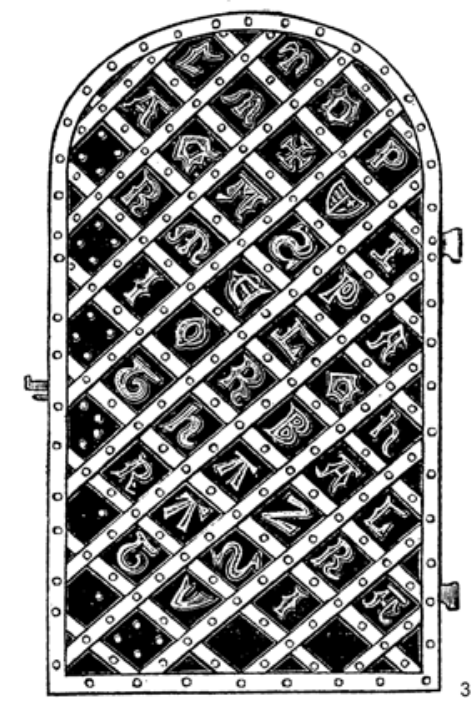

Obr. 15. 1 - Žehra - Spišský hrad, torzo gotického zvona; 2 - Bratislava, fragment medenej misy s iniciálou „m“ a korunkou,t. j. Maria - král’ovná nebies; 3 - Leles - premonštrátsky kláštor, gotické dvere s nápismi.

Abb. 15. 1 - Žehra - Zipser Burg, Torso einer gotischen Glocke; 2 - Bratislava, Fragment einer Kupferschale mit Initiale „m“" und Krone, d. h. Maria - Himmelskönigin; 3 - Leles - Prämonstratenserkloster, gotische Tür mit Inschriften. 
a stretávame sa s nimi aj na podobných dverách z mad’arskej Rudabánye, ktoré boli vyhotovené v 14. storočí (Bárányné-Oberschall 1941, 10).

Nálezový fond s inskripciami uzatvárame torzom zvona, nájdeného ešte v roku 1969 pri výskume Spišského hradu (obr. 15:1). Majuskulné litery ARI na ňom (výška 3,8cm), vsadené medzi dvojice plastických liniek, sú pravdepodobne z nápisu AVE MARIA GRACIA PLENA. Nález zhodnotil popredný kampanológ J. Spiritza $(2008,67)$. Jeho pôvod predpokladá v znamenitej spišskonovoveskej dielni majstra Konráda Gaala a podla písmen ho datoval do druhej polovice 14. storočia. Autor pripúšt’a jeho odliatie pre Spišský hrad, čo je asi nepravdepodobné. Skôr možno uvažovat' o druhotnej surovine pre potreby hradu v neskorších storočiach. Vzhl'adom na rozsah skúmaného materiálu, ale hlavne publikačnú obmedzenost', sa budeme d’alším pamiatkam venovat' na inom mieste. Latinské príslovie vyjadrené v podtitulku tohto príspevku - „Význam slov je duchom zákona“ - má stále svoju platnost', a to nielen v právnej rovine.

Výskum projektu Stredoveké nápisy na Slovensku bol podporený z grantu APVV-0237-11.

\section{Literatúra}

ALEKSIĆ, M., 2007: Mediaeval Swords from southeastern Europe. Material from 12th to 15th Century. Belgrade.

ANDRZEJEWSKA, A., 1997: Jeszcze o tzw. ceramice husyckiej z terenu Kujaw na przykladzie znalezisk ze Zglowiączki, woj. Włocławskie, Archaeologica Historica Polona 5, 177-186.

ARENS, F. von, 1971: Die usprügliche Verdendung gotischer Stein- und Tonmodel mit einem Verzeichnis der Model in Mittelrheinischen Museen, Mainzer Zeitschrift 66, 106-131.

BALEGOVÁ, J., 2003: Šarišský hrad v časoch Juraja Vernera, Pamiatky a múzeá, č. 4, 18-21.

BÁRÁNYNÉ-OBERSCHALL, M., 1941: Régi magyar vasmüvesség. Budapest.

BLÁHA, J., 1974: Historická archeologie k dějinám městské školy u sv. Mořice v Olomouci. In: Okresní archiv v Olomouci 1973, 29-35. Olomouc.

BOTOŠ, A., 2011: Rimavská Sobota v stredoveku a vo včasnom novoveku vo svetle archeologických nálezov. Rigorózna práca, FF UKO, Bratislava.

BRACHA, K., 1991: Magia słowa. Świadectwa teológow i wierzenia popularne w XV wieku, Kwartalnik Historiczny 98, č. 3, 17-32.

BREKLE, H. E., 1999: Das typograophische Prinzip. Versuch einer Begriffserklärung. In: Inchrift und Material. Inschrift und Buchschrift (Koch, W.-Steininger, Ch., edd.), 207-212. München.

BŘICHÁČEK, P.-HEREIT, P., 1996: Renesanční kachle a motívy biblických hrdinů ze západních Čech, SZM XIII, 130-133.

BRINKMANN, H., 1936: Die Darstellungen des Apostels Petrus. Düsseldorf.

BYLINA, S., 1984: Nowa dewocja, postawy wiernych i kult maryjny w Europie środkowej późnego średniowiecza, Studia Claromontana 5, 4-32.

ČAMBAL, R.-CHOMA, I., 2010: Románsky meč a hlavica meča z Bacúrova, ZbSNM CIV - Archeológia $20,113-116$.

ČAPLOVIČ, D., 1990: Novšie poznatky o stredovekom vývoji mesta a života obyvatelov Košíc - Die neuesten Erkenntnisse über die mittelalterliche Entwicklung und das Leben der Einwohner von Košice, AH $15,87-98$.

ČOVAN, M., 2011: Stredoveká a ranonovoveká kultúra východného Slovenska vo svetle najnovších epigrafických, paleografických a heraldických zistení, Slovenská archivistika 46, 94-111.

- 2013: Sepulkrálie na Šariši v stredoveku a ranom novoveku. In: Epigraphica et Sepulcralia 4. Fórum epigrafických a sepulkrálních studií (Roháček, J., ed.), 73-116. Praha.

- 2014: Kultúrno-spoločenské pomery ranonovovekého Bardejova na pozadí meštianskych sepulkrálií. In: Epigraphica et Sepulcralia 5. Fórum epigrafických a sepulkrálních studií (Roháček, J., ed.), 41-61. Praha.

- 2015: Šarišské zvony z obdobia stredoveku a raného novoveku. In: Historica 49. Zborník k 65. narodeninám profesora Leona Sokolovského, 24-50. Bratislava.

- 2016: Historické nápisy zo Šariša do roku 1650: Corpus Inscriptionum Slovaciae 1. Martin.

DĄBROWSKA, M., 2013: Piec jako nośnik idei?, Archaeologia Historica Polona 21, 209-237. DOI: https:// doi.org/10.12775/AHP.2013.010 
DENKSTEIN, V., 1969: Böhmische Prunksporen aus dem 15. Jahrhundert, SbNM A XXIII, 165-195.

DOMBART, T., 1914/1915: Der Name Jesu (Das Monogram IHS), Die christliche Kunst 11, 257-269.

DUNNING, G. C., 1967: Late Medieval Jugs with Lettering, Medieval Archaeology 11, 233-241.

- 1974: A Late Medieval Jug with Lettering from Canons Ashby, Northamptonshire, Medieval Archaeology $18,160-163$

DURDÍK, T.-KAŠPAR, V., 2000: Forma na odlévání dělových koulí z hradu Vimperku, CB 7, $293-307$.

ENGELKING, A., 1988: Magiczna moc słowa w polskiej kulturze ludowej. In: Język a kultura.t.1. (Anusiewicz, J.-Bartmiński, J., edd.), 263-278. Wrocław.

FARKAŠ, Z., 2015: Stredoveké hrádky v Malých Karpatoch. In: Hradiská - svedkovia dávnych čias, 127145. Dolná Mariková.

FAVIER, J., 2006: Zlato a koření! Zrod obchodníka ve středověku. Praha.

FEDOROV, G. B.-POLEVOJ, A. L., 1973: Archeologija Rumynii. Moskva.

ELIADE, M., 1974: Sacrum, mit, historia. Warszawa.

ELIAS, N., 1980: Über den Prozess der Zivilisation. Frankfurt/Main.

FRANZ, A., 1909: Die kirchlichen Benediktionen im Mittelalter. II. Freiburg im Breisgau.

FRANZ, R., 1969: Der Kachelofen. Graz.

FINGERLIN, I., 1971: Gürtel des hohen und späten Mittelalters. München - Berlin.

FORSTNER, D. OSB, 1990: Świat symboliki chrześcijańskiej. Warszawa.

FRÖHLICH, J., 2002: Středověké odpadní jamy v Písku, AVJČ 15, 139-161.

GEIBIG, A., 1991: Beiträge zur morphologischen Entwicklung des Schwertes im Mittelalter. Offa-Bücher 71. Neumünster.

GERLACH, S., 1987: Ein Töpferofen mit Abfallgrube des 14. Jahrhunderts in Würzburgg, Bayerische Vorgeschichts-Blätter 52, 133-230.

GŁOSEK, M., 1973: Znaki i napisy na mieczach średniowiecznych w Polsce. Wrocław - Warszawa Kraków - Gdańsk.

- 1984: Miecze środkowoeuropejskie z X-XV w. Warszawa.

GŁOSEK, M.-KAJZER, L., 1976: Miecze z napisami grupy DIC w Europie środkowej, Kwartalnik HKM 24 , č. 4, 217-248.

- 1977: Zu den mittelalterlichen Schwertern der Benedictus-Gruppe, Waffen- und Kostümkunde 19, č. 2, 117-128.

GORMAN, M. R., 2005: INGERLII. A Continuing Tradition in Early Mediaeval Swordsmithing. In: The spring 2005 London Park Lane Arms Fair (Oliver, D. A., ed.), 30-36. London.

GROßMANN, G. U., 2010: Einführung in die historische und kunsthistorische Bauforschung. Darmstadt.

GRUIA, A.-M., 2013: Religious Representations on Stove Tiles from the Medieval Kingdom of Hungary. Cluj-Napoca.

GUREVIČ, A. J., 2016: Jedinec a společnost středověkého západu. Praha.

GUERRA, L., 2008: Inscriptions and Communication in Anglo-Saxon England. AD 600-900. Utrecht.

HAJDU, H., 1931: Lesen und Schreiben im Spätmittelalter. Pécs.

HANSMANN, L.-KRISS-RETTENBECK, L., 1966: Amulett und Talisman. München.

HATHÁZI, G., 2004: A XIV. századi feliratos csatok elterjedésének kérdéséhez. In: „Qusi liber et pictura“. Tanulmányok Kubinyi András, 207-220. Budapest.

HAZLBAUER, Z., 1998: Krása středověkých kamen. Praha.

- 2005: Sygnatury garncarskie na gotyckich i renesansowych kaflach czeskich, Kwartalnik HKM 53, 205-217.

HEINDEL, I., 1986: Ave-Maria Schnallen und Handtruwebratzen, Zeitschrift für Archäologie 20, 65-79.

HEJNA, A., 1983: Kovový nálezový inventář z hradu Vizmburku, k. ú. Havlovice, o. Trutnov - Das Fundinventar metallischer Gegenstände aus Burg Vizmburk, Katastralgemeinde Havlovice, Bez. Trutnov, AH 8, 491-501.

HILGERS, W., 1969: Lateinische Gefässnamen Bezeichnungen, Funktion und Form römischer Gefässe nach den antiken Schriftquellen. Beih. Bonner Jahrbuch 31. Düsselforf.

HOLČÍK, Š., 1978: Stredoveké kachliarstvo. Bratislava.

HOLL, I., 1991: Gotische Tonmodel in Ungarn, Acta Archaeologica Scientiarum Hungaricae 43, 315-336.

- 1993: Renaissance-Öfen. Mittelalterliche Ofenkacheln in Ungarn V, Acta Archaeologica Academiae Scientiarum Hungaricae 45, 247-299.

HOLTMANN, G. F., 1993: Untersuchung zu mittelalterlichen und frühneuzeitlichen Messern. Göttingen.

HORBACZ, T. J.-MIKOŁAJCZYK, A.-WOJDA, L., 1980: Ceramika husycka z Włocławka. In: Zapiski Kujawsko-Dobrzyńskie. Seria C, 25-50. Włocławek. 
HOŠŠO, J., 1996: O tzv. bratislavských pohároch (Príspevok k poznaniu keramických gotických pohárov), ZbSNM XC - Archeológia 6, 197-204.

HRAŠKOVÁ, E.-KHÜRTY, L.-RAGAČ, R.-ŠIMKOVIC, M., 2001: Pamiatkový prieskum a zist'ovací archeologický výskum kostola a zaniknutého benediktínskeho kláštora v Rimavských Jánovciach Denkmal- und archäologische Erforschung der Kirche und des untergegangenen Benediktinerklosters in Rimavské Janovce, AH 26, 279-298.

CHYBOVÁ, H., 2009: Kroměříž zmizelá a znovu objevená aneb historie ukrytá pod dlažbou města. Kroměříž.

JÁNSKÁ, E., 1965: Hrad Jána Roháče z Dubé Sion, Sborník muzea v Kutné Hoře řada A - historická, č. 6-7, 5-72.

KAJZER, L., 1994: Zur problematik der sog. Hussitenkeramik in Polen, CB 4, 299-306.

KALMÁR, J., 1957: Armbrust-Pfeilspitzen als Rangabzeichen, Folia Archaeologica IX, 153-166.

- 1959: A Füleki (Filakovo) vár XV-XVIII. századi emlékei. Régészeti füzetek Ser. II-4. szám. Budapest.

- 1971: Régi magyar fegyverek. Budapest.

KLOOS, R. M., 1980: Einführung in die Epigraphik des Mittelalters und der frühen Neuzeit. Darmstadt.

KOBIELUS, S., 2000: Krzyż Chrystusa. Od znaku i figury do symbolu i metafory. Warszawa.

KOCH, R., 2012: Ein Bronzeschüssel aus Münsterschwarzach und Weitere karolingerezeitliche Schlüssel östlich de Rheins. In: Grosso Modo. Quellen und Funde aus Spätantike und Mittelalter (Krohn, N.Koch, U., edd.), 181-188. Weinstadt.

KOCH, W., 2007: Inschriftenpaläografie des abendländischen Mittelalters, und der frühern Neuzeit. Wien - München.

KÖHLER, W., 1905: Die Schlüssel des Petrus-Versuch einer religionsgeschichtlichen Erklärung von Math. XVI, 18-19, Archiv für Religionwissenschaft 8, 214-243.

KOHOUTEK, J., 1997: Výzkum hradu Helfenštejna v Moravské bráně - Erforschung der Burg Helfenštejn, AH 22, 235-247.

KOSEL, F.-J., 2001: Jodocus Vredis und die Kartause Weddern. In: Jodocus Vredis. Kunst aus der Stille. Eine Klosterwerkstatt der Dürerzeit, 61-164. Borken.

KOŠTA, J.-HOŠEK, J., 2014: Early Medieval Swords from Mikulčice. Brno.

KRAJÍC, R., 1982: Výzkum středověké keramické pece v Táboře, AR XXXIV, 269-277.

- 1991: Stavební železo a uzavírací mechanismy na vrcholně středověkých lokalitách Táborska - Eiserne Baubeschläge und Verschliessungsmechanismen von den hochmittelalterlichen Lokalitäten in der Gegend von Tábor, AH 16, 323-343.

- 2001: „Husův hrneček“ ze středověkého Sezimova Ústí - „Hus-Töpchen“ aus der mittelalterlichen Stadt Sezimovo Ústí. In: Ve službách archeologie II. př́rodovědné metody v archeologii a antropologii (Hašek, V.-Nekuda, R.-Unger, J., edd.), 129-130. Brno.

LABUDA, J., 2000: Pozoruhodné nálezy zo Starého mesta Banskej Štiavnici - Einzigartige Obole von Karl Robert von der Bergbaufundstelle Glanzenberg in Banská Štiavnica (Schemnitz), AH 25, 7-24.

- 2016: Chladné zbrane 10.-16. storočia pochádzajúce z rieky Váh. Magisterská práca, FF MU, Brno.

LAMPART, F., 2012: Vrcholnostredoveký meč zo Spišského hradu, Vojenská história 16, č. 1, $125-132$.

LAURIOUX, B., 1999: Tafelfreuden im Mittelalter. Augsburg.

LEEUW, G. wan der, 1978: Fenomenologia religii (preklad). Warszawa.

LEHOCZKY, T., 1871: A leleszi levéltár és egy régi vasajtó, Archeologiai ertesítő V, 9. sz., 274-280.

LEVINAS, E., 1998: Całość i nieskończoność (preklad). Warszawa.

LINLAUD, M., 2014: Serrures médiévales VIIIe-XIIIe siècle. Rennes.

LOSKOTOVÁ, I., 2012: Brněnské kachle se starozákonními hrdiny - Brünner Kacheln mit alttestamentarischen Helden, AH 37, 663-678.

LUBELCZYK, A., 2005: Renesansowe kafle z Rzeszowa i Czudca. In: Gotické a renesančné kachlice v Karpatoch (Chovanec, I., ed.), 183-203. Trebišov.

MANDEL, G., 1993: Der Schlüssel geschichte und Symbolik der Schlüssel und Schlösser. Stuttgart.

MÁCELOVÁ, M., 1999: Gotické kachl'ové pece z banskobystrickej radnice - Die gotischen Kachelofen aus dem Rathaus in Banská Bystrica, AH 24, 409-420.

- 2009: Signovaný pohár z konca 16. storočia z Banskej Bystrice, ŠZ AÚ SAV 46, 31-32.

MĚŘÍNSKÝ, Z., 2007: Hrad Rokštejn. Brtnice - Brno.

MIKOŁAJCZYK, A., 1978: Radełkiem na glinianych naczyniach..., Z otchłani viekow XLIV, č. 4, $279-284$.

MICHNA, P. J., 1990: Die archäologische Enforschung des historische Kerns der Stadt Olomouc, Archäologische Stadkernforschungen in Sachsen, Beiheft 19, 159-166.

MÜLLER-WILLE, M., 1970: Eines neues ULFBERHT - Schwert aus Hamburg, Offa 27, 65-91.

NAGY, P.-NAGYOVÁ., 2015: Register tehliarskych značiek na Slovensku. SNM Bratislava. 
NECHVÁTAL, B., 1976: Středověká studna v Plzni - Solní ulici. Praha.

NADOLSKI, B., 2001: Spotkanie tradycji gestu i slowa. In: Idee chrześcijańskie w życiu Europejczyka. Język. Pismiennictwo. Sztuki plastyczne. Obyczaje. Część I, 83-92. Łódź.

NEKUDA, V., 1975: Pfaffenschlag. Zaniklá středověká ves u Slavonic. Brno.

- 1985: Mstěnice. Zaniklá středověká ves u Hrotovic. 1. Brno.

NEKUDA, V.-REICHERTOVÁ, K., 1968: Středověká keramika v Čechách a na Moravě. Brno.

NICKEL, H., 1969: Böhmische Prunkpfeilspitzen, SbNM A XXIII, 101-163.

NOVOTNÝ, B.-FUHRHERR, V., 1971: Katalóg archeologickej zbierky Západoslovenského múzea v Trnave. Bratislava.

OAKESHOTT, E., 1964: The sword in the Age of Chivalry. London.

- 1991: Records of the Medieval Sword. Woodbridge.

OHLY, F., 1958/1959: Vom geistigen Sinn des Wortes im Mittelalter, Zeitschrift für deutsches Altertum und deutsche Literatur 89, 1-23.

OPITZ, C. u. a., edd., 1993: Maria in der Welt. Marienverehrung im Kontext des Sozialgeschichte. 10.-18. Jahrhundert. Zürich.

OSE, I., 1992: Entdeckung einer Kachelserie der 16. Jahrhunderts „Die zwölf sieghaften Helden des Alten Testaments" in Lettland, Keramos Hft. 138, 45-54.

OTTAWAY, P.-ROGERS, N., 2002: Craft, Industry and Everyday Life: Finds from Medieval York. London.

PANKHOFER, H., 1974: Schlüssel und Schloß. 2. vyd. München.

PARÁDI, N., 1965: Későközépkori feliratos díszű cserépedények, Folia archaeologica XVIII, $155-168$.

PÁTKOVÁ, H., 2014: Česká středověká paleografie. Praha.

PELA, W., 2008: Znaleziska ostróg z zapiętkami z drugiej połowy XV w. w Europie Środkowej, Kwartalnik HKM 58, č. 2, 197-206.

PETRI, H.-BEINERT, W., 1996: Učení o Marii [preklad]. Olomouc.

PITTIONI, R., 1976: Schwarzhafnerei aus dem Stift Heiligenkreuz bei Baden, NÖ, Archaeologia Austriaca 59/60, 175-224.

POKORNÁ, J., 2002: Archeologický výzkum v zahradě nemocnice Na Františku v Praze 1, Archaeologica Pragensia 16, 119-140.

POLLA, B., 1962: Zist’ovací historicko-archeologický výskum na bratríckom tábore na Zelenej hure v Hrabušiciach, SlArch X, 253-279.

- 1971: Kežmarok. Výsledky historicko-archeologického výskumu. Bratislava.

PROCHNOW, D., 1966: Schönheit und Schloss, Schlüssel, Beschlag. Düsseldorf.

PROKISCH, B.-KÜHTREIBER, TH., edd., 2004: Der Schatzfund von Fuchsenhof. Linz.

PRIX, D.-ROHÁČEK, J., 2009: Epigrafický kontext arabských číslic. In: Epigraphica - Sepulcralia II (Roháček, J., ed.), 195-213. Praha.

RADOMĚRSKÝ, P., 1964: Nejstarší dějiny Louňovic pod Blaníkem (I), ČNM CXXXXIII, č. 2, 1-24.

RAFFAELI, U., 1996: Oltre la porta Serrature, chiavi e forzieri dalla preistoria all'età moderna nelle Alpi orientali. Trento.

RAVDONIKAS, V. I., 1933: Nadpisi i znaki na mečah Dneprostroja. Moskva.

REGTEREN, H. H. van-ZANTKUYL, H. J., 1969: A Medieval House Site in Amsterdam, Bereliechten ROB 19, 233-266.

REICHERTOVÁ, K., 1965: Středověká keramika ze Sezimova Ústí, Tábora a Kozího hrádku. Archeologické studijní materiály III. Praha.

REUTER, M. v.-SCHOLZ, M., 2005: Alles Geritzt: Botschaften aus der Antike. München.

RICHTER, M., 1969: Výzkum v Sezimově Ústí v 1. 1966-1968, AR XXI, 768-782.

- 1978: Středověká keramika ze Sezimova Ústí. Katalog. České Budějovice.

ROYT, J., 2013: Slovník biblické ikonografie. Praha.

RUTTKAY, A., 1971: Dva stredoveké meče s nápismi zo Slovenska, AR XXIII, 163-168, $253-256$.

- 1975: Waffen und Reiterausrüstung des 9. bis zur ersten Hälfte des 14. Jahrhunderts in der Slowakei (I), S1Arch XXIII, 119-216.

- 1976: Waffen und Reiterausrüstung des 9. bis zur ersten Hälfte des 14. Jahrhunderts in der Slowakei (II), SlArch XXIV, 245-395.

- 1978: Umenie kované v zbraniach. Bratislava.

SEDLÁČKOVÁ, H. a kol., 2016: Renaissance and Baroque Glass from the Central Danube region. Brno.

SCHOKNECHT, U., 1969: Eiserne Schwerter mit Inschrift aus Mecklenburg, Ausgrabungen und Funde $14,212-217$.

SCHOLZ, M., 2000: Freigeformte römische Kochtöpfe mit Herstellersignaturen aus dem westlichen Hochrheintal, Archäoplogische Nachrichten aus Baden Heft 63, 38-48. 
SCHREINER, K., 1991: Laienfrömmigkeit - Frömmigkeit von Eliten oder Frömmigkeit des Volkes? In: Laienfrömmigkeit in späten Mittelalter (Schreiner, K.-Müller-Lucker, E., edd.), 1-78. München.

- 2003: Maria. Leben, Legenden, Symbole. München.

SCHULZE-DÖRLAMM, M., 2012: Zwei ungewöhnliche Bronzeschlüssel der Karolingerzeit - ein Amulettschlüssel aus Mainz und ein „Petrusschlüssel“ aus Alzey. In: Grosso Modo. Quellen und Funde aus Spätantike und Mittelalter (Krohn, N.-Koch, U., edd.), 189-202. Weinstadt.

SLIVKA, M., 1978: Stredoveké hutníctvo a kováčstvo na východnom Slovensku. 1. čast', Historica Carpatica IX, 217-263.

- 1980: Stredoveké hutníctvo a kováčstvo na východnom Slovensku. 2. čast', Historica Carpatica XI, 218-288.

- 1981: Stredoveké hutníctvo a kováčstvo na východnom Slovensku. 3. čast', Historica Carpatica XII, 211-276.

- 1987: Pozoruhodný nález stredovekých slnečných hodín na Kláštorisku, Nové obzory 29, 181-188.

- 2001: Interakčný charakter kláštora v hospodárskom systéme stredoveku - Interaktionscharakter des Klosters in wirtschaftlichen System des Mittelalters, AH 26, 299-322.

- 2002: Symbolika výzbroje a výstroja - Symbole der Ausrüstung, AH 27, 589-605.

- 2002a: Cirkevné dejiny v archeologických prameňoch, Pamiatky a múzeá, č. 3, 8-12.

- 2003: Vzácny nález dýky zo Šarišského hradu. In: Ve službách archeologie IV. Sborník k 75. narozeninám prof. PhDr. Vladimíra Nekudy, DrSc. (Hašek, V.-Nekuda, R.-Unger, J., edd.), 229-231. Brno.

- 2013: Pohl'ady do stredovekých dejín Slovenska. Martin.

SLOBODOVÁ, M., 2010: Knižné kovania - ku genéze knižnej väzby. Diplomová práca, FF UKO, Bratislava. SONNTAG, J., 2008: Klosterleben im Spiegel des Zeichenhaften. Berlin.

SPIRITZA, J., 1996: Nielen epitafy sú epigrafmi, Slovenská archivistika 31, č. 2, 61-85.

- 2008: Magister Iohannes Wagner de Nova Villa, pôvodca zvonov a bronzových krstitel'níc z rokov $1475-$ 1513, Z minulosti Spiša XVI, 59-84.

STALSBERG, A., 2011: Ulfberht problems. Identification. Documentation. Variants of inlays. Dating problems. In: Non sensistis gladios. Studia ofiarowane Marianowi Głoskowi w 70. rocznicę urodzin (Lawrynowicz, O.-Maik, J.-Nowakowski, P. A., edd.), 389-403. Łódź.

STEGER, H., 1961: David rex et Propheta. Nürnberg.

SZENDREI, I., 1896: Ungarische Kriegsgeschichtliche Denkmäler in der Millennium Landesausstellung. Budapest.

ŠEBESTOVÁ, M., 2005: Kachlice z Komorského dvora v Banskej Štiavnici. Diplomová práca, FF UKO, Bratislava.

ŠEDIVÝ, J., 2006: Ukryté v písme. K datovaniu stredovekých pamiatok na základe ich nápisov. In: Byzantinoslovaca I (Daniš, M., ed.), 244-252. Bratislava.

- 2008: Epigrafické písma z územia Slovenska medzi neskorou gotikou a renesanciou, Zborník Filozofickej fakulty Univerzity Komenského - Historica 47, 7-26.

- 2009 Littera epigraphica sepulcralium mediaevalium Hungariae Superioris. In: Epigraphica et sepulcralia 2 (Roháček, J., ed.), 289-312. Praha.

- 2014: Latinská epigrafia. Dejiny a metodika výskumu historických nápisov zo Slovenska. Bratislava.

- 2015: Písmo na stredovekých zvonoch z územia Slovenska, Monument revue 4, č. 2, $26-34$.

ŠLÉZAR, P., 2016: Archeologické poznanie malého královského mesta na Morave. Dizertačná práca, FF UKO, Bratislava.

ŠMAHEL, F., 1990: Silnější než víra: magie, pověry a kouzla husitského věku, Sborník vlastivědných prací z Podblanicka 30, 31-51.

ŠTAJNOCHR, V., 1998: Dva etnoikonografické exkurzy do novověké keramiky a keramika v archeologii Zwei ethnoikonografische Exkurse zur neuzeitlichen Keramik und zur Keramik in der Archäologie, AR L, 35-41.

ŠVEHLA, J., 1901: Nádobí kuchyně a stolu staročeského. In: Zpráva o činnosti rady městského musea v Táboře za rok 1901, 1-31. Tábor.

- 1911: Nádoby s nápisy z Ústí Sezimova a Kozího Hrádku, ČSPS, č. 19, 9-14.

- 1930: Farní kostel a fara v Ústí Sezimově, JSH 3, 87-90.

THOMA, J., 1993: Včasnostredoveký meč s nápisom Ulfberth v expozícii militárií na hrade Krásna Hôrka, ŠZ AÚ SAV 29, 277-280.

TEMESVÁRY, F., 1961: Kulcstípusok és zármechanizmusok fejlődése a XV. században, Folia a rchaeologia $13,151-181$.

TOMÁŠOVÁ, B., 1999: Nálezy z hradu Solivar, Studia Archaeologica Slovaca mediaevalia II, 173-192. 
TORBRÜGGE, W., 1970/1971: Vor- und frühgeschichtliche Flussfunde. Zur Ordnung und Bestimmung einer Denkmälergruppe, Bericht RGK 51/52, 1-146.

TRAUBE, L., 1907: Nomina Sacra. Versuch einer Geschichte der christlichen Kürzung. München.

TRELIŃSKA, B., 1991: Gotyckie písmo epigraficzne w Polsce. Lublin.

TWEDDLE, D., 1984: The Coppergate Helmet, Forvännen 78, 105-112.

TYMONOVÁ, M., 2012: Renesanční kachle s dvanácti biblickými hrdiny a tyrany z českého Slezska Renaissancekacheln mit zwölf biblischen Helden und Tyrannen vom tschechischen Gebiet Schlesiens, AH 37, 679-689.

ULLMANN, K., 1961: Dolchmesser, Dolche und Kurzwehren des 15. und 16. Jahrhunderts, Waffen- und Kostümkunde, Hf. 1, 1-13.

ULRYCHOVÁ, E.-HAZLBAUER, Z., 1998: Renesanční kachle se zobrazením starozákonního soudce Jepteho - Eine Renaissance-Ofenkachel mit der Abbildung des alttestamentlichen Richters Jepte, AR L, 636-644.

VATTAI, E., 1956: A Körmendi lelet (XIV.-XV. sz.), Archaeologiai értesítő 83, 67-75.

VRTEL, A., 2012: Keltské oppidum v Bratislave. In: Dejiny Bratislavy 1 (Šedivý, J.-Štefanovičová, T., edd.), 164-178. Bratislava.

WAGNER, T. G.-WORLEY, J.-HOLST-BLENNOW, A.-BECKHOLMEN, G., 2009: +INNOMINEDOMI$\mathrm{NI}+$ Medieval Christian invocation inscriptions on sword blades, Waffen- und Kostümkunde 51, 11-52.

WACHOWSKI, K., 2013: Emblemata mediaevalia profana. Przykład Polski. Wrocław.

WAIDACHER, F., 1965: Zur Bedeutung von Schloß und Schlüssel im Volksglauben und Volksbrauch. In: Schloss und Schlüssel. Alte und neue Schlosserkunst. Katalog, 11-13. Graz.

WALDHAUSER, J.-SOSNOVEC, P., 2004: Nová archeologické zjištění v hradech Pojizeří, CB 9, $383-386$.

WALCHER-MOLTHEIN, A. von, 1924: Formodel für Feingebäck und Zuckerwerk, Belvedere 5, Heft 24, 201-220.

WEGELI, R., 1902-1905: Inschriften auf mittelalterlichen Schwertklingen, Zeitschrift für historische Waffenkunde 3, 177-183, 218-225, 216-268, 290-300.

WESTPHALEN, P., 2002: Die Eisenfunde von Haithabu. Neumünster.

WEISMAYER, J., 1994: Život v plnosti. Dějiny a teologie duchovního života. Kostelní Vydří.

WOLF, F., 1956: Ein neuer Reizer-Schlüssel, Mitteilungen der Österreichischen Numismatischen Gesellschaft IX, č. 8, 57-59.

WORMSTAL, A., 1896: Jodocus Vredis und das Kartäuserkloster zu Wedderen bei Dülmen in Westfalen. Münster i. W.

ZACHAR, L., 1987: Keltské umenie na Slovensku. Bratislava.

ZAJIC, A., 2014: Epigrafische und heraldisch-sphragistische Bemerkungen zum Wiener Neustädter Schatzfund. In: Der Schatzfund von Wiener Neustadt (Hofer, N., ed.), 238-263. Wien.

ZSÁMBÉKY, M., 1983: 14-15. századi magyarországi kincsleletek, Művészettörténeti Értesitő 32, $105-129$.

ŻYGULSKI, Z., jun., 1975: Broń w dawnej Polsce. Warszawa.

ŽÁK-MATYASOWSZKY, F., 2003: Antické nápisné pamiatky na území Slovenska. Nitra.

ŽÁKOVSKÝ, P., 2008: Tauzované kopí s nápisem Viktorina ze Žerotína, CB 11, 473-482.

ŽEGKLITZ, J., 1987: Pozdně gotické kachle se jmény hrnčířů, AR XXXIX, 655-671.

- 2012: Prints and other artwork models for motives on stove tiles from the Czech lands. Renaissance stove tiles as a means for disseminating ideas and culture during the age of Reformation, Studies in PostMedieval Archaeology 4, 25-112.

- 2012a: Grafické a další předlohy motivů na kachlích z českého prostředí. Renesanční kachle jako prostředek šíření idejí a kultury doby reformace - Prints and other artwork models for motifs on stove tiles in Bohemia. Renaissance stove tiles as an agent in the spread of Reformation ideas and culture, AR LXIV, $265-319$.

„Sensus verborum est anima legis.“

\section{Zusammenfassung}

\section{Inschriften im mittelalterlichen Material aus dem Gebiet der Slowakei I.}

Die hier vorgelegte Arbeit ist Teil des in Angriff genommenen Projektes „Mittelalterliche Inschriften in der Slowakei“, das auf dem Boden der Philosophischen Fakultät der 
Comenius-Universität in Bratislava koordiniert realisiert wird. Die Arbeit umfasst archäologisches Material, auf welchem sich verschiedene Inschriften, bzw. bereits die Namen der Meister von Erzeugnissen, Invokationen hauptsächlich religiöser Bedeutung oder Initialen (z.B. auf Schlüsselköpfen) befinden. Das geschriebene Wort hat im Mittelalter häufig einen höheren geistigen Sinn, einen sensus spiritualis. In dem Beitrag wird eine Interpretation angestrebt, und zwar vor allem unter Heranziehung von biblischen Texten. Auch der grundlegende und sehr wichtige paläographische Aspekt wird nicht übergangen. Wir weisen auf eine ganze Skala von Schriftformen hin, angefangen von den nicht stabilen romanischen Varianten bis hin zur kanonisierten gotischen Majuskel- oder Miniskulschrift. Die Arbeit fällt somit in den breiten interdisziplinären Umkreis der Forschung, und im hier vorgelegten I. Teil werden Keramikfunde im weitesten Sinne des Sortimentes, Waffen (vor allem Schwerter und Messer), Schlüssel, Glaserzeugnisse und einige Gusseisen- und Schmiedearbeiten ausgewertet.

Die Inschriften auf mittelalterlicher Tafelkeramik liegen in zweierlei Ausführungen vor, einmal geritzt (auf Bechern aus Bratislava und aus Košice - Abb. 1) sowie in Rädchentechnik ausgeführt, häufig während des ganzen 15. Jahrhunderts. Im Hinblick darauf, dass sie in Böhmen (in der Umgebung von Tabor) am massenhaftesten vorkamen, erhielten sie die inadäquate Bezeichnung Hussitenkeramik (hauptsächlich in der polnischen Fachliteratur). In der Kachelproduktion tauchen Inschriften einerseits als sprechend auf, d.h. sie bezeichnen Darstellungen von Aposteln, Propheten oder Heiligen, oder auch in Form von Namen ihrer Hersteller (Abb. 5, 6). Bemerkenswert ist eine Kollektion von Kacheln mit sogenannten alttestamentarischen „Helden“ von der Grabung auf Burg Scharosch (Šariš), auf denen sich die Jahreszahl 1553 befindet (Abb. 7, 8). Die bekannte Nürnberger Grafikvorlage des Kupferstechers Georg Pencz aus dem Jahr 1531 diente zur Herstellung der Kachelmatrizen, und zwar entweder in einer Kaschauer (Košice) oder Preschauer (Prešov) Werkstatt (der Auftrag wurde von dem Humanisten Georg Werner vermittelt, der damals Präfekt der Burg Scharosch war). Auch dem Torso eines Lehmmodels von der Grabung an einem Kartäuserkloster (mit Analogien in Worms und Olmütz) und einer aus demselben Kloster stammenden Keramik-Sonnenuhr $(22,7 \times 18,7 \mathrm{~cm})$ wurde Beachtung geschenkt (Abb. 6:4). Das Zifferblatt ist mit arabischen Ziffern versehen, die in der zweiten Hälfte des 15. Jahrhunderts im mitteleuropäischen Raum häufiger auftauchen.

Auf Schwertern finden sich häufig Inschriften, vor allem auf frühmittelalterlichen vom nach ihren ersten Herstellern benannten Typ ULFBERTH und INGERLII (aus Krásna nad Hornádom), die als Qualitätsmarken in der Zeitspanne vom 9.-11. Jahrhundert benutzt wurden. Schwerter mit invokativen Inschriften (12.-14. Jahrhundert) bilden den Interessensgegenstand von mehreren Forschern (hauptsächlich Wegeli, Głosek, A. Ruttkay, Labuda, Lampart u. a.), deren Auflösung der Abkürzungen nicht immer das Wesentliche der Hersteller erfassen (vom Verfasser des vorliegenden Beitrags wurden die Inschriften einer gewissen Neuinterpretation unterzogen). Ein eigenes Kapitel wurde Prachtmessern gewidmet, deren aus Metall bestehende und versilberte Griffhülsen die Inschrift $A V E$ MARIA bzw. maria gratis oder nur maria tragen (Banská Štiavnica - Abb. 12:1, Burg Solivar - Abb. 12:2, und weitere ausländische Analogien, Abb. 12:4-6).

Behandelt werden auch spätgotische Schlüssel, deren runde Köpfe die Initialen A, V und P (Abb. 13) zieren. Die Fachliteratur bringt mit dem Buchstaben „P“ eindeutig den Apostel Petrus in Verbindung, dem Christus den Schlüssel des Himmelreichs anvertraute (Matthäus 16, 18-19). Häufiger kommt der Buchstabe „V“ (Veritas) oder „A“ (Agnitio) vor, deren Sakralität biblisch erklärt und begründet wird. Dadurch wird auf das Faktum hingewiesen, dass es sich dabei nicht nur um ein gotisches Zierelement handelte.

Aus der Renaissancezeit sind Funde von Glasbechern mit Ritzdekor bemerkenswert, die Namensinschriften und die Jahreszahl 1569 (Fund aus Bratislava - Abb. 14:1) und 159(?) (Fund aus Banska Bystrica - Abb. 14:2) aufweisen. Abschließend wird der Fund eines Glockentorsos aus der zweiten Hälfte des 14. Jahrhunderts erwähnt, der von einer auf der Zipser Burg durchgeführten Grabung stammt und die Majuskeln „ARI“, also die auf Glocken übliche Inschrift „AVE MARIA GRATIA PLENA“ trägt. Einzigartig ist eine Eisentür aus dem ehemaligen 
Prämonstratenserkloster in Leles, auf welcher die Inschrift besagt, dass „Propst Dominik im Jahr 1400 sie zu Ehren Caspar, Melchior und Balthasar erneuert hat". Die Namen der heiligen drei Könige sollte apotropäische Wirkung haben, um den Raum des Archivs und der Schatzkammer, den sie ursprünglich verschloss zu beschützen (heute befindet sich die Tür im Ostslowakischen Museum in Košice).

$\mathrm{Zu}$ den einzelnen analysierten Materialien werden nahe und entfernte Analogien aufgeführt, wobei der Verfasser im vorliegenden Beitrag auch auch ihren ursprünglichen Aufbewahrungskontext und ggf. auf ihre Werkstattherkunft eingeht. In dem sich in Vorbereitung befindenden II. Teil werden Inschriften auf Schmuckmaterial (Ringe, Fibeln, Schließen, Riemenzungen) sowie auf in Fülle vorkommenden spätmittelalterlichen Buchbeschlägen analysiert.

Das Forschungsprojekt Mittelalterliche Inschriften in der Slowakei wurde von der Fördermaßnahme der Agentur zur Förderung von Foschung und Entwicklung APVV-0237-11 gefördert.

Doc. PhDr. Michal Slivka, CSc., Katedra archeológie Filozofickej fakulty Univerzity Komenského, Gondova 2, SK 81102 Bratislava, Slovenská republika,michal.slivka@uniba.sk 
